\title{
The distribution of village names based on pre-Christian Finnic personal names in the northern Baltic Sea area
}

The article studies pre-Christian Finnic anthroponyms and their spread in the northern Baltic Sea area at the end of Middle Ages (c. AD 1520). This is done by analysing village names based on pre-Christian Finnic personal name elements. The primary research material consists of various editions of documents from the 15th and 16 th centuries. The analysis demonstrates that village names based on pre-Christian Finnic anthroponyms are most densely located in Varsinais-Suomi, Häme, Northern and Eastern Estonia, Southern Karelia, the Karelian Isthmus and Eastern Ingria. The first four areas are home to significant Iron Age settlements. It seems that the use of the pre-Christian Finnic name elements under investigation originally started in these areas and spread eastwards.

1. Introduction

1.1. Historical background and study area on a map

1.2. Pre-Christian Finnic anthroponyms

1.3. The concept(s) of a village

1.4. The concept(s) of village name

2. Research material

3. Methodology

4. Results

4.1. Collected names

4.2. The geographical spread of Finnic village names

4.3. Areal differences in the spread of name elements

5. Discussion

5.1. Remarks on the geographical distribution of the Finnic village names

5.2. The spread of Finnic village names compared to archaeological data

5.3. The development and spread of Finnic pre-Christian personal names in the light of archaeology and linguistics

6. Conclusions 


\section{Introduction}

This article presents an overview of the geographical distribution of preChristian Finnic personal names (anthroponyms) in the northern Baltic Sea area during the Middle Ages (c. 1100-1500). This is done by searching for village names based on pre-Christian Finnic personal name elements mainly in editions of 15 th- and 16th-century documents. The result is compared to archaeological and linguistic information. Thus, this work is not only about the use of old pre-Christian Finnic personal names but also sheds light on the linguistic and cultural changes that took place in the Baltic Sea area during the Middle Ages (cf. Leibring 2016: 211-212). ${ }^{1}$

For a long time, onomastics have been a vital part of studies concerning Finno-Ugric languages and their history. As early as the 19th century, linguists interested in Finno-Ugric languages noticed that toponyms located in northeastern Europe were important sources for their studies (e.g. Sjögren 1861). Soon after, researchers understood the significance of personal names as well (e.g. Gottlund 1872; Forsman 1894). Thus, from the late 19 th century onwards, researchers interested in the history of the FinnoUgric languages have been dealing with names. Lately, researchers such as Pauli Rahkonen (2013) and Denis Kuzmin (2014a) have studied place names and revealed new details about the history of Finnic languages. Very much connected to this work are articles recently published by Saulo Kepsu (2015a) and Janne Saarikivi (2017), where they conduct research on toponyms based on pre-Christian Finnic personal names. In addition, an article written by the author (2019) focuses on the Finnish village names derived from pre-Christian Finnic personal names.

Thus, the value of names as a historical source is moderately well-known among scholars interested in the history of Finnic languages and tribes. Despite this, there are still many opportunities in the study of personal names that have not been fully exploited. For example, most of the abovementioned studies concentrate on present-day nomenclature. Even though place names tend to survive for long periods, it is logical to assume that names used in old documents are better sources for describing the past than the contemporary names. Moreover, those few studies that focus on Finnic

1. An example of this is the influence of Western anthroponymic systems: in the 16th century, six out of the seven most popular first names were the same in Finland and Sweden (Kiviniemi 1982: 70). 
personal names mentioned in old documents are often limited to certain geographical areas and lack a broader perspective on the developments of Finnic pre-Christian anthroponyms (e.g. Karlova 2014; Sobolev 2017).

Explicit mentions of personal names in old documents would be the best source material for studying the distribution of pre-Christian Finnic personal names. The problem is, however, that the northern part of the Baltic Sea area has been a relatively remote place, where written culture did not emerge until the Middle Ages. As a result, most of the preserved medieval documents concerning the northern Baltic Sea area are from the 15th and 16th centuries. To give an example, a major collection of Finnish medieval documents called Finlands medeltidsurkunder (FMU) contains slightly more than 6,700 edited documents, whereas Svenskt Diplomatariums huvudkartotek över medeltidsbreven (SDHK) has more than $40,000 .{ }^{2}$

Another problem is that the documents from the 15th and 16th centuries include only a few pre-Christian Finnic personal names. Persons mentioned in the documents usually have (Eastern and Western) Christian main names, such as Anders, Fedko, Heinrich, Mikulka or Olof. Areal, cultural and temporal differences in documentation are considerable as well. For example, taxation documents concerning the 16th-century Tammela parish in the province of Häme (Swedish Tavastland) have peasants with names in the form of a Christian name followed by a patronym (e.g. Erik Persson in Kaukjärvi village). In Tyrvää parish in the province of Satakunta, peasants are named differently, with the Christian name followed by various kinds of bynames (e.g. Staffan Musta 'black', Clemet Äiänpoia 'son of Äijä', Jöns Koskenlaskia 'white water rower'). Moreover, it is often difficult to distinguish whether a person's byname is a "given name" or an inherited one. For example, there was a farmer called Morthen Tojuo ( Toivo 'hope') in Tyrvää parish in 1546 and, from 1585 onwards, Per Frantsson, later known as Per Toiffuo, owned the farm. ${ }^{3}$ (SAYL.)

2. Finlands medeltidsurkunder ('Medieval sources of Finland') (published 1910-1935) includes different kinds of editions of medieval documents (from the gth century to 1530) concerning Finland. Svenskt Diplomatariums huvudkartotek över medeltidsbreven ('The Main Catalogue of Diplomatarium Suecanum') is a digital register that contains editions of medieval documents related to Sweden (most of the Finnish documents are also included, since the western and southern parts of Finland belonged to Sweden during the Middle Ages.) (https://sok.riksarkivet.se/sdhk, retrieved 1 November 2018).

3. Translations are based on modern-day speech and made by the author unless noted otherwise. 
Considering the above-mentioned difficulties, it is understandable that the spread of Finnic personal names cannot be studied solely based on anthroponyms mentioned in old documents. There are, however, other possibilities. Pre-Christian personal names can be found in epithets (e.g. Kuningas), patronyms (Illonpoika, Toivalov), surnames (Kurki), names of villages (Hyvälempe-lä) or names of homesteads (Lempiä-lä). ${ }^{4}$ (Kiviniemi 1982: 36; Rintala 2008: 21-22.) Of the above-mentioned 'secondary sources', village names are the most adequate (cf. Kepsu 2015a). This is why this article focuses on medieval village names based on pre-Christian Finnic personal names (from now on, the expression Finnic village names is used as a synonym).

The structure of the article is as follows: First, a short overview of the history of the area under investigation is given in Section 1. The second section introduces background information on pre-Christian Finnic anthroponyms and village name systems in different medieval documents. The third section provides a description of the research materials and methods. The next section presents the results and the geographical spread of village names based on pre-Christian Finnic personal names. Finally, in the fifth section, conclusions are drawn from the results of the study and discussed.

\section{I.I. Historical background and study area on a map}

Most of the research results regarding the early history of Finnic tribes (c. AD 800-1400) are based on fragmentary written sources and scarce archaeological findings. Nevertheless, it is assumed that the area inhabited by Finnic tribes was remote and sparsely populated compared to the central areas of Europe (e.g. Venice or the Holy Roman Empire). In the beginning of the Viking Age (c. AD 8oo), the most influential powers in Northern Fennoscandia were Scandinavian groups coming from Denmark and Sweden. In addition to these, the influence of Slavic people was fast increasing. During the 12th, 13th and 14th centuries, these groups were expanding their influence and fighting each other in order to control lands and trade in Northern Fennoscandia. (CHS: 60-221; CHR: 45-210.)

4. Kuningas 'king', Illonpoika 'son of Illo', Toivalov 'son of Toiva' (toivo 'hope') and Kurki 'crane' (and a famous Finnish noble family). The village name Hyvälempelä consists of the personal name element Hyvälempi (Hyvä 'good, nice, kind' + lempi 'lovely, love, favourite') and a locational suffix (-lA). 
By the end of the 15th century, the Teutonic Order controlled the present-day areas of Estonia and Latvia. The Danish king had been forced to sell the kingdom's territory in Northern Estonia. The Realm of Sweden controlled Western Finland and the southern coastal area all the way to the city of Vyborg on the Karelian Isthmus. The eastern parts of Fennoscandia and the eastern parts of the Gulf of Finland were ruled by the city-state of Novgorod. (CHS: 392-410; Raninen \& Wessman 2015: 338-359.)

Map 1 displays the approximate regions covered by the materials used in this study. It is important to recall that during the Middle Ages, borders in the northern Baltic Sea area were not strict lines between nations but rather spheres of interest between the most powerful actors in the region. The borders were changing constantly during the Middle Ages, and especially in sparsely populated areas, the division between different powers remained unclear well into the early modern period (cf. Korpela 2002). The thick black dotted line represents the approximate outer borders of the late 15th-century Diocese of Åbo, which was the eastern part of the Realm of Sweden. ${ }^{5}$ The northern parts of present-day Finland were still an area not permanently controlled by any government. The eastern parts of Finland were controlled by the Novgorod Republic. On the Karelian Isthmus and in Eastern Finland, the border is based on the Treaty of Nöteborg (1323), where the Realm of Sweden and Novgorod signed a peace treaty and, for the first time, established their border. Only this southern part of the border is indisputably described in the different versions of the treaty. The border remained an official division between Sweden and Novgorod until 1595.

At the end of the 15th century, the administration of Novgorod's so-called original lands was divided into five parts, each known as a pjatina 'fifth' (Ronimus 1906: 5). The thin dotted line depicts the borders of the fifths. ${ }^{6}$ The names of these areas are also displayed on the map. The western border of Novgorod, beginning from the south, stretched to the Pskov Republic, Livonia (or the Teutonic Order) and the Diocese of Åbo. One may notice that

5. The borders of Diocese of Åbo are based on the maps presented in the book Atlas of the settlement in Finland in the 1560s (SAK) (1973). This atlas depicts the locations of villages that were considered part of the Swedish taxation area in the 1560 .

6. The borders of Novgorod's territory are based on maps presented by K. A. Nevolin (1853).

7. These are Bežetskaja, Derevskaja, Obonežskaja, Šelonskaja and Vodskaja. The transliteration is according to ISO 9. 
the lines between Novgorod and Sweden overlap with each other. This again emphasises how unclear the borderline really was between these two powers. It also depicts how Finnish settlers from the Diocese of Åbo had established new settlements in the disputed border area during the 16th century.

The black line depicts the current border of Estonia. During the Middle Ages, Estonia was part of Livonia, which also included the current area of Latvia. This approximately corresponds to the area conquered by the Teutonic Order during the crusades of the 13th century. Livonia was divided into many sub-regions governed by different ecclesial or secular powers (cf. Zetterberg 2007: 79-129).

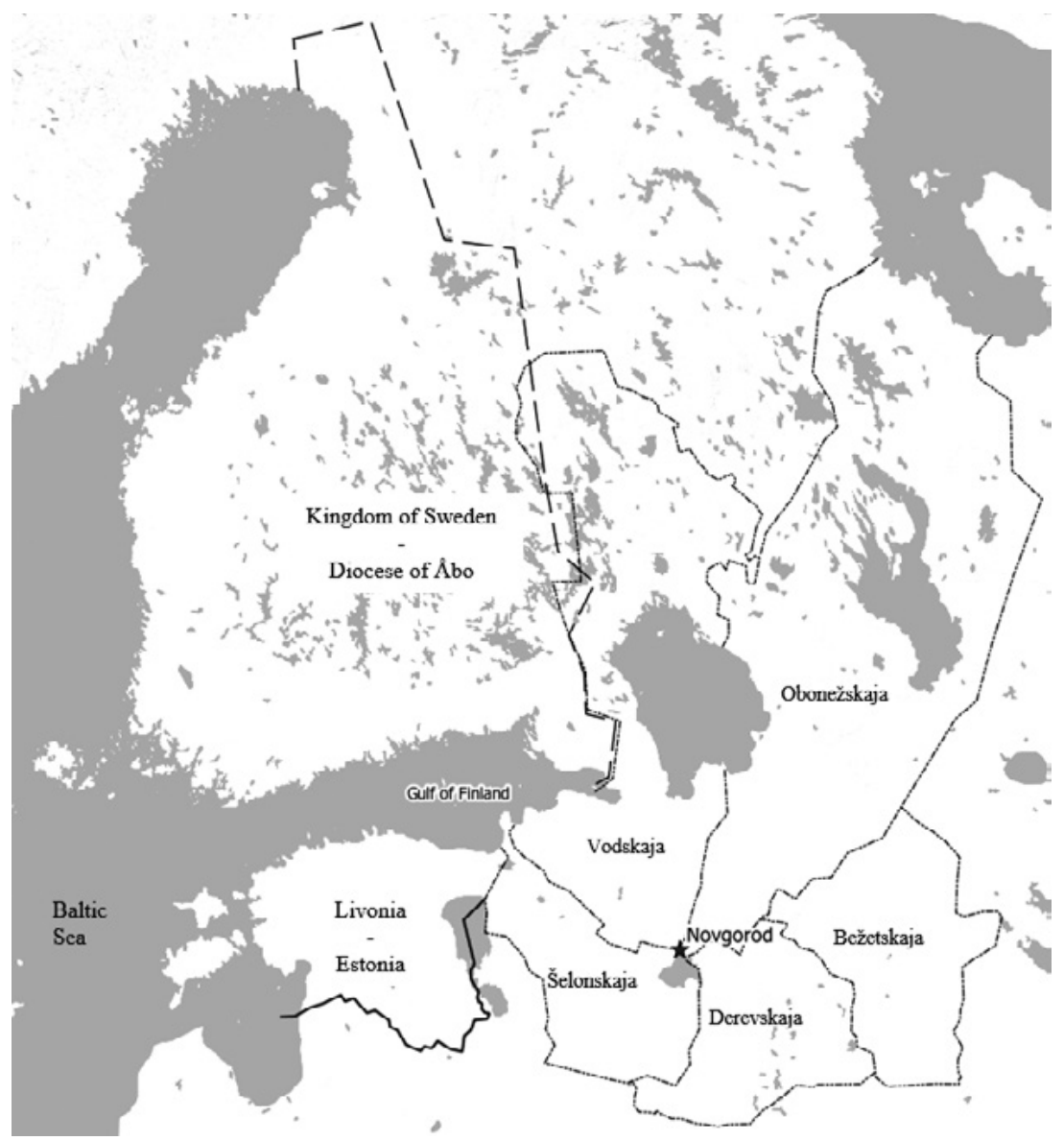

Map 1: The study area (map drawn by the author). Base map: Stamen Toner Lite. 


\section{I.2. Pre-Christian Finnic anthroponyms}

There are many studies presenting the topic of pre-Christian Finnic personal names from different perspectives, but Detlef-Eckhard Stoebke's dissertation (1964) remains the most comprehensive research conducted to this day. ${ }^{8}$ For this reason, the following introduction is based on his work.

Stoebke (1964: 109-135) states that Finnic names were composed in three different ways: there were simplex names (e.g. Lempo, Mieli, Iha), simplex names with a suffix (Lemmi-tty, Miela-kka, Iha-ttu) or complex names (Hyvä-lempi, Mieli-valta, Iha-lempi). Semantically, names were probably originally descriptive and transparent. For example, the name Hyvälempi consists of two parts: hyvä 'gut' (English 'good') + lempi 'liebe' ('love, dear') (ibid. 136, 139). It is likely that attributes used in a name were often based on the hopes and wishes of the name givers. People could also be named based on their appearance or characteristics. The exact meaning of name elements was not always the primary principle of naming. Naming children after their predecessors is one example of this kind of custom. ${ }^{9}$

Many different name elements have been regarded as pre-Christian in previous studies. This work adheres to Stoebke's idea of pre-Christian Finnic personal names. He has used twofold criteria when asserting which name elements were used in old Finnic anthroponyms: the name element must be found in various areas inhabited by speakers of Finnic languages and it cannot be considered a borrowed name (Stoebke 1964: 82). The 22 name elements identified by Stoebke are: Auva, Heimo, Hyvä, Iha, Ikä, Ilma, Jou(t)si, Kaikki, Kauk(k)a, Kirja, Kyllä, Lempi, Meeli, Neuvo, Päivä, Toivo, Un(n)i, Unta, Valta, Viha, Vihta and Vilja (ibid. 83-108).

It must be noted that this is not a complete list of names. There are not enough sources to create an accurate depiction of a millennium-old

8. Altough Stoebke speaks of "Finnic personal names" ("ostseefinnischen Personennamen"), he has included Saami names as well. In contemporary linguistic research, Saami is not considered a Finnic language (Lehtinen 2007: 82).

9. Old tax accounts show that it was common to name children after their predecessors. For example, the following list presents householders of the homestead Knuutti in the village of Vataja in old Tyrvää (Swedish Tyrvis) parish: householder Lars Jönsson (1540), Jöns Larsson (1565) and Lars Jönsson (1569) (SAYL). The Saami people had similar customs in the 18th century: the first son was named after his father's father and the second one after his mother's father (Valtonen 2017: 306-307). 
personal name system. Nevertheless, Stoebke's name elements lay a good foundation for this kind of study, and they are widely accepted by other researchers. For instance, Kepsu (2015a: 130) has 17 of Stoebke's chosen name elements in his list of 60 probable pre-Christian Finnic personal name elements used among the Finnic tribes. ${ }^{10}$ Moreover, this study can indicate whether all of Stoebke's name elements are adequate. This being the case, the chosen name elements should be encountered in old village names.

\section{I.3. The concept(s) of a village}

The concept of a village differs depending on the institution that has overseen the documentation. The main fact is that a village was a taxation unit. In 16th-century Sweden, a village (Swedish by) meant a tax unit that included one or more homesteads. However, this system was not homogenous (see Seppälä 2009). In Ostrobothnia, for example, the same settlement could have been considered a village in secular documentation but not in ecclesial documentation, and vice versa (SAK: 16).

In medieval Livonia, the administration systems differed from region to region. The current area of Estonia was divided into many smaller areas controlled by the Church or the German nobility. ${ }^{11}$ In the Livonian countryside, settlement patterns often remained similar to the way they were before the conquest of the Teutonic Order. The basic formation of settlements was a village that consisted of several homesteads (Šnē 2008: 92). Surviving medieval documents from the area of present-day Estonia imply that the village was a basic administrative concept (cf. Johansen 1938; LCD). Documentation was mainly produced in Latin and (Low) German, but later, Swedish was used as well. Between 1561 and 1721, parts of Estonia were under Swedish rule.

The documents preserved in the area of Novgorod were not compiled by the city-state itself. The Grand Duchy of Moscow had subjugated the

10. The name elements chosen by Kepsu (2015a: 130) are Ahti, Aika, Aina, Ano, Arpa, Asi, Auva, Hala, Heimo, Himo, Hurtta, Hyry, Hyvä, Iha, Ikä, Ilma, Ilo, Kaipa, Kauko, Kilpa, Kirja, Kyllä, Leina, Lempi, Mieho, Mieli, Miero, Monta, Muoto, Neuvo, Niha, Nousia, Paha, Para, Parka, Pelko, Päivä, Raha, Rahko, Raukka, Saira, Salli, Satta, Sota, Suuri, Tapa, Tenho, Toivo, Tora, Unta, Urja, Uska, Utu, Vaino, Valta, Viha, Vihti, Vilja, Voipa and Vähä.

11. The Kingdom of Denmark controlled the northern parts of Estonia all the way until 1346. 
city-state and its belongings before the end of the 15th century (CHR: 211239). The Muscovites ordered documentation after the conquest had been finalised (Ronimus 1906: $3^{-6}$ ). The documents were written in so-called Russian chancery language. ${ }^{12}$ A typical village was commonly called a derevnja (деревня). The size of a village could vary. The smallest ones were the size of one homestead and the largest ones consisted of up to 69 homesteads (Ronimus 1906: 80). The expression selo (село) referred to a village (usually a larger one) with a church (Nevolin 1853: 98).

To summarise, it is fair to say that the definition of a village was not homogenous. However, there are also some similarities between different areas. First, most of the villages were originally homesteads (cf. Kepsu 2015a: 128). A homestead turned into a village when more fields were cleared or obtained and more homesteads were established. In addition, a single homestead could be counted as a village if the authorities had reason to do so, for example, if a settlement was far from the others. ${ }^{13}$

\section{I.4. The concept(s) of village name}

A village name is another concept that needs to be explained in more detail. Village names can be divided into two groups: names based on names of natural places and names based on personal names. The names of central, visible or important places in nature have been used to name villages because these places have been significant to the inhabitants (cf. Kepsu 2015a: 128). Village names based on nature names are regarded in the Finnish onomastic literature as older than those derived from personal names (cf. Ainiala et al. 2012: 92-93; Alanen 2004: 135). ${ }^{14}$

12. Chancery language was developed for the purposes of the Muscovite government and its need for bureaucratic documentation from the 15 th century onwards (Worth \& Flier 2012).

13. For instance, a homestead called Kolkko in the former Kyrö parish (nowadays Ikaalinen parish) was considered a village in ecclesial taxation, but in secular taxation it was a homestead belonging to the neighbouring village of Sikuri (SA: 103).

14. Kepsu (2018: 11) has presented a good summary on the theory of estimating the relative age of a village name. In addition, in Finland, the villages whose names are derived from nature names are often larger and more central than those whose names are based on personal names. Regional differences do, however, play a significant role in this matter. 
Village names based on personal names, in turn, are generally derived from homestead names, which, again, were named after their founders. Thus, many homestead names include personal names (Kiviniemi 1990: 167). Consequently, some village names are supposedly based on preChristian personal names. (Kepsu 2015a: 128.)

It should be noted that a village name based on a pre-Christian personal name does not always mean that a person or persons with the same name would have lived there. So-called transferred names (see Brink 2016) could have affected the spread of the Finnic village names as well. ${ }^{15}$ In other words, a name could be based on a settler's village or homestead of origin. Regardless of whether the name is transferred or not, the distribution of Finnic village names still shows a certain naming culture.

Another thing to bear in mind is that the geographical distribution of Finnic village names does not necessarily indicate migration of Finnic settlers but perhaps rather the spread of Finnic cultural influences. It is a well-known fact that personal names are borrowed from language to language more readily than other language elements (Ainiala et al. 2012: 136). The expansion of Christian personal names in Northern Europe during the early Middle Ages is a good example of this (ibid.).

It is noteworthy that within such a wide study area, one can find different ways of naming villages and other settlements. For example, in the western and southern areas of Finland, village names based on nature names are less popular than in the east and north (cf. Kepsu 1987: 65). This can be explained, at least partly, by the fact that the villages are usually older in many places in southern Finland, and the population density used to be higher as well (Kepsu 2018: 11; Raninen \& Wessman 2015). The same phenomenon can be seen in the documents concerning the area of the Novgorod Republic. In the northern regions, village names based on nature names (e.g. lake names) are common, whereas in areas with a higher population density, names based on anthroponyms are more popular. ${ }^{16}$ Naturally, this is also

15. Transferred names are names that are transferred from one place to another. It has been a fairly common phenomenon in Finnic areas that homesteads established by settlers are named after their home villages (Kepsu 2010: 48-49).

16. The truth is, however, more complicated. In the Onega fifth, for example, most of the village names used in the census books are derived from nature names, but military documents compiled in the beginning of the 18th century show that the names used by the locals differed from the official ones. Often, these local names were based on personal names. (Vitov 1962: 34.) 
due to the fact that the landscape is different. For example, on the Karelian Isthmus, where sandy ridges and lakes are widely characteristic, the landscape is visibly different from the flat plateau of the Izhora uplands. ${ }^{17}$

Differences in livelihoods are another reason for heterogeneous village naming conventions. In the beginning of the Middle Ages, densely populated areas were located in terrain that was suitable for ancient cultivation technologies and were thus inhabited all year round. The ownership of land was an important concept in these regions, and personal names were used to name different possessions (e.g. Vihattu-la, a homestead owned or established by Vihattu). In contrast, lifestyles based on hunting, fishing or slash-and-burn cultivation, which existed in more remote and wooded areas in eastern and northern Finland, for example, required a more mobile lifestyle. ${ }^{18}$ The possession of land was probably not that important or welldefined for people with this kind of lifestyle, as long as there was enough land for everybody (Korpela 2004: 233; Voionmaa 1969: 188). On the other hand, it is important to remember that this is only a simplified comparison. In reality, the concept of land ownership has varied in different places and at different times. Using Eastern Finland as an example, the court and taxation documents from the 16th-century province of Savo (Swedish Savolax) indicate how important land ownership had become despite the region still being sparsely populated (Pirinen 1982: 83-88, 331-333, 349-350). Nonetheless, in the northern parts of 16 th-century Savo, most of the place names mentioned in the documents are based on nature names (Kepsu 2015b).

In addition to this, there is no certainty that a name mentioned in old documents was the one that local people actually used. For example, scribes in 16th-century Novgorod had a specific descriptive way of naming the smaller and less significant villages. These were often named after bigger villages, for example Д. другая Копанииа на Систи ('(village) second Kopanica at the River Sisti') (NPK III: 501), or after the names of the rivers, lakes, hills and other natural formations nearby, for example Д. надъ

17. For example, Knyazeva \& Eydlina (2018) provide a good overview of the landscape in Northwest Russia.

18. In this case, a mobile lifestyle refers to a way of living where peasants and their families kept moving while looking for new slash-and-burn sites, hunting grounds and fishing waters. There were, however, significant differences in this kind of lifestyle depending on place and time. In the 16th century province of Savo, this could mean that a family had a permanent homestead in a village but during the summer they stayed closer to their possessions (Pirinen 1982: 63-64, 293). 
озеромъ надъ Валгомонъ ('(village) upon Lake Valgomon') (NPK III: 929). It is unlikely that locals used these kinds of descriptive forms of their villages (Kepsu 2010: 11).

Names tend to change over time, but village names are usually preserved well (cf. Hausen 1924). As is often stated in onomastics, the more central and important a place is, the more likely the original name is to have survived for a long time (Ainiala et al. 2012: 21). This can be applied to village names as well. Furthermore, the establishment of written documents has affected the survival of names: the use of settlement names became more stabilised because they were recorded and used continuously for administrative purposes.

However, there are many regional differences when it comes to the preservation of names. The Middle Ages and the beginning of the early modern period were a rather peaceful and prosperous period in many regions in Finland, which means there were no dramatic changes in the lifestyle for centuries. On the other hand, many areas in Estonia and Ingria were stages for numerous battles and plunders during the 16th and 17th centuries. Consequently, many villages were destroyed and abandoned.

Moreover, the scribes who wrote the documents had an impact on how the village names were presented. ${ }^{19}$ The customs for naming villages in medieval accounting differed depending on the time and place. King Gustav (Vasa) I of Sweden renewed many aspects of the taxation system during the first decades of the 16th century, which led to more comprehensive and accurate documentation (Seppälä 2009: 18). ${ }^{20}$ Documents from the area of the Novgorod Republic were a product of a certain order coming from the Grand Prince of Moscow (Nevolin 1853: I-XII). The ruler wanted to know how much income the Grand Duchy of Moscow should acquire from the newly conquered area (ibid.). The officers appointed to this task probably did not visit all the villages they documented. Instead, local priests and trusted men were used as informants (Ronimus 1906: 6).

As stated earlier, the present-day area of Estonia was controlled by many different powers during the Middle Ages (cf. Zetterberg 2007: 76). This means that the documentation was not systematic. The documents that have survived are inconsistent, and especially in southern Estonia, the

19. In addition, the style of documentation prepared by the Church was somewhat different from secular documentation. The sources used in this study are mainly of the latter type.

20. Gustav I (Vasa) of Sweden ruled in 1523-1560. 
oldest documents are comprehensive only from the 17th century onwards (Evar Saar, oral information 2 March 2018). In addition, due to the actions of local aristocrats and the Church, many villages were incorporated into lands owned by these two powers and, consequently, their names were lost (Zetterberg 2007: 129).

\section{Research material}

The research materials used for this study approximately cover the area presented in Map 1. Village names from the Diocese of Åbo have been collected from the book Suomen asutus 156o-luvulla ('The settlements in Finland in the 156os') (SA), which includes all of the villages mentioned in the ecclesial and secular documents during the 1550 os and 6os. ${ }^{21}$ The source contains 7,798 settlements, but the number of names is approximately 8,000 because the names of some villages varied depending on the document. ${ }^{22}$

The sources concerning the area of the Novgorod Republic are edited versions of 15 th- and 16th-century documents known as the Novgorod census books (Russian переписные книги or писиовые книги). ${ }^{23}$ The third part of the book series Novgorodskie pistsovye knigi (NPK III) covers the southern and western parts of the Vodskaja pjatina ('fifth'). ${ }^{24}$ The northernmost part of the Vodskaja fifth is covered in books titled Perepisnaja okladnaja kniga po novugorodu votskoj pjatiny (POKV I-II). ${ }^{25}$ The original

21. The province of Savo (part of the Diocese of Åbo) is a special case, because villages are only occasionally documented as taxation units in the 16th-century documents. Peasants are mostly divided into larger groups responsible for paying taxes (referred to in Finnish as arviokunta, neljänneskunta and kymmenyskunta). The 17th-century documents already include villages with names. Researchers have used these later names and compared them to the epithets that were used for peasants in 1561-62. By doing so, they have been able make a reliable supposition of which villages already existed in the $1560 \mathrm{~s}$ (e.g. 1561: Grels Auffuinen > 1664: Auffwila by). (SAK: 14-15.)

22. This number also includes manors and seat farms because many of them were originally villages. For example, the crown had established a manor called Mustiala based on the village located in that place earlier (cf. Alanen 2004: 140-141).

23. These documents are also referred to as scribe books, cadastres or land registers in English.

24. Новгородские писцовые книги ('Scribe books of Novgorod').

25. Переписная окладная книга по Новугороду Вотьской пятины ('Census tax book of Novgorod's Vodskaja fifth'). 
documents from the Vodskaja fifth seem to be fairly well preserved, as only a few pages of the original document are missing. This applies to the documents of the Derevskaja fifth from 1495 (NPK I-II) as well. The original documents for the other administrative fifths have not been preserved as well. Thus, the research material consists of census books from various years. The book Materialy po istoričeskoj geografii Novgorodskoj zemli: Šelonskaja pjatina po piscovym knigam 1498-1576 g.g. (MIN) includes the areas of the Šelonskaja fifth. ${ }^{26}$ Piscovyje knigi Obonežskoj pjatiny (PKOP) contains editions of documents concerning the Obonežskaja fifth. ${ }^{27}$ The Bežetskaja fifth is covered in NPK VI, which contains information from the years 1501, 1545, 1551 and 1564. All of these areas can be seen on Map 1.

As mentioned in Section 1.3, the Novgorod census books were produced because the Grand Duchy of Moscow wanted to maintain records of its possessions in the area of Novgorod. The form of documentation in each of the books is almost identical. They contain information about the possessions of former and current landowners (e.g. nobles, authorities, Churches and monasteries).

It is difficult to give an estimation of how many villages are mentioned in the Russian sources listed above. POKV II, which covers a bit less than one fifth of the sources page-wise, contains approximately 3,800 village names. Thus, the overall number of Russian village names should be around 20,000. The problem is, however, that many of the villages are mentioned several times. For example, the taxable objects of one village could be shared by three different boyars, which means that the village is mentioned whenever the possessions of each man are presented.

Medieval and 16th-century documents relevant to the present-day area of Estonia have their origins in many different sources. It would have been too time consuming to go through all of the documents for this study. However, the handbook of Estonian place names Eesti kohanimeraamat ('Dictionary of Estonian place names') (KNR) covers a large portion of the villages mentioned in old documents. Thus, this study relies on the information presented in the handbook. KNR contains circa 4,500 village

26. Материалы по исторической географии Новгородской земли: Шелонская пятина по писцовым книгам 1498-1576 г.г. ('Materials of historical geography of Novgorod land: the Šelonskaja fifth according to census books 1498-1576').

27. Писцовые книги Обонежской пятины ('Scribe books of the Obonežskaja fifth'). 
names (Estonian küla). Out of these, those that are presumably derived from the 16th century or earlier are included. The dating is based on the information presented in the book itself.

It should be emphasised that the research material does not include original documents, but rather editions of them. Consequently, there is the possibility that the editors have transcribed some of the village names incorrectly. Furthermore, even the original documents may contain misleading information. Scribes have written the name as they have understood it or how it has been told to them. Misspellings, analogies or translations of names probably occurred often..$^{28}$ One must also remember that 16th-century scribes in Estonia, Finland or Russia did not have any common rules for writing.

\section{Methodology}

The aim of this study has been to find village names based on pre-Christian Finnic personal name elements and locate them on a map. The following section explains how this process was carried out and according to what principles. The names were mainly collected by studying the material page by page. The village names are readily listed in the source Suomen asutus 1560-luvulla (SA). In the case of KNR, names that have been considered village names were selected for the study. The Russian sources are more heterogeneous, but expressions such as derеvnja (деревня), selo (село) and

28. Misspelling occurred partly because scribes were used to using certain letters and syllables while writing and those were not suitable for writing down Finnic words. For example, some Finnic diphthongs have been confusing for Russian scribes, such as in the case of names with the element Kauko: Гавгуево (Gavguevo) (POKV I: 358). Analogy, in turn, means that scribes adapted Finnic names or parts of them into names or words that were more familiar to them. This is difficult to recognise if other attestations of the name do not reveal the analogy. It is also difficult to know if the analogy has been created by a scribe or by the users of the name themselves (cf. Vitov 1962: 29-30). A good example of (folk) analogy is the name of the medieval parish Kivennapa (Swedish Kivinebb), which most likely derives from the old Swedish word kiffuinebb 'wooden fort' (Kepsu 2018: 203) but which has been probably mistaken by the locals for the Karelian words kivi 'stone' and napa 'navel, belly button'. The translation of names happened in some areas, but personal name elements were apparently not translated. Some possible cases occured in Ingria, such as Долгино (долгий 'long; tall') (POKV I: 170), which could be the same village as Pitkälä (pitkä 'long; tall'), a village that has references from the 17th century onwards (Kepsu 2010: 342). 
their abbreviations make village names more easily recognisable. The Russian material has also been analysed by reading it through page by page, but due to the vast amount of data, the likelihood of missing some village names is high. To minimise this possibility, editions of documents were converted to editable text format. Then, the different kinds of letter combinations, which could originate from Finnic personal name elements, were used as search words in accordance with approximate string matching (also known as fuzzy string search).

From the sources mentioned above, only village names that are (highly probably) derived from the chosen pre-Christian Finnic name elements have been selected. The list of name elements included in the searches, which is based on Stoebke's research, is presented in Section 1.3. To reduce the probability of incorrect selections, many place name and personal name surveys are used when examining whether a name is based on a pre-Christian Finnic anthroponym. The main surveys concerning current area of Finland are the following: FSBN (Finlandssvenska bebyggelsenamn 'Finland Swedish settlement names'), SPNK (Suomalainen paikannimikirja 'Book of Finnish place names') and USNK (Uusi suomalainen nimikirja 'New book of Finnish names'). Saulo Kepsu's studies have been of great help when dealing with the village names in Northwest Russia. His publication Kannaksen kylät ('Villages of the Karelian Isthmus') (2018) and his manuscript Inkerin pogostat: vanha nimistö ja asutus ('Pogosts of Ingria: old nomenclature and settlement') (2010) address many of the village names relevant to this study. In addition, the following sources have been useful in examining the names located in Northwest Russia: publications of Kuzmin (e.g. 2014a-b), Matveev (e.g. 2015), Mullonen (e.g. 2008) and Saarikivi 2006. A further relevant source has been $\mathrm{KNR}$, an etymological survey of Estonian place names.

One must remember, however, that there are no certain etymologies when speaking of names that are hundreds of years old. Many of the problems related to the quality of the sources were already discussed in Section 2. In addition, there are other peculiarities connected to the studied village names that must be considered when attempting to uncover the origins of names. First of all, many of the Finnic personal name elements derive from appellatives, which were or still are used in everyday speech. It is possible that on some occasions, the naming principle of a chosen village name is not based on a personal name, but rather a descriptive noun. For example, the name element Kauko derives from the word kauka, the basic meaning of which in Finnish is 'remote, far away' (SSA s.v. kauka). Earlier, kauka 
also meant 'long' (SPNK s.v. Kauklahti). All of these meanings are common among Finnish toponyms (cf. Kiviniemi 1990). Thus, some of the names starting with Kauk- might be based on a descriptive word rather than a personal name. This is obvious, for example, in the case of the village name

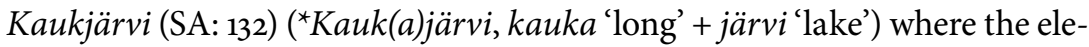
ment kauka describes the shape of the lake. ${ }^{29}$ The village name Kaukurla (SA: 21) in Mynämäki parish could as well derive from descriptive noun, because it has been located next to a long bay. ${ }^{30}$ On the other hand, those Finnic and Russian village names that are based on anthroponyms often have specific suffixes attached to them. For instance, the Finnic locational suffix $-l A$ is frequently used in cases where a personal name is the naming principle (cf. Kepsu 1987; Rintala 2008: 22). Similarly, Russian possessive suffixes -icy-/-icy-and -ov-/-ev-are usually found in those village names that are based on anthroponyms (cf. Kepsu 2010: 33-34; Mullonen 2008: 185-186).

In addition, the southern and eastern regions of the study area in Northwest Russia are incompletely covered in the onomastic surveys and sources mentioned above. Further scrutiny is thus needed when analysing village names located in these areas. For example, there are toponyms in the Vologda region starting with the element Iga-, which is often thought to be derived from Finnic Iha (cf. Rintala 2008; Saarikivi 2017: 19). However, similar words are found, for instance, in the Mari language and thus, A. K. Matveev has thought that many of the Ig- names in the Vologda region are of Mari origin (2015: 166-167). Furthermore, it is problematic that there are many old Russian personal names resembling Finnic ones (cf. Superanskaja 2009). For instance, the above-mentioned Iga has been used as a form of the name Igor (which is itself derived from Old Norse name Ingvar) (ibid.).

In the case of village names located in the territory of Novgorod (or the Grand Duchy of Moscow), a list of contemporary Russian toponyms is used as comparative material in order to identify cases that need more research..$^{31}$ As an example, the geographical spread of the settlement names starting with Vil- in European Russia indicates that this name element is

29. The village of Kaukjärvi is located in southern Finland in the former province of Häme (Swedish Tavastland).

30. Mynämäki is located in Southwest Finland (Varsinais-Suomi).

31. The list is based on the names listed in a place name registry on the webpage Geoserver (http://www.geonames.org/), accessed 12 November 2018. The page contains approximately 360,000 place names. 
popular in areas next to the border of Finland, near the city of Perm and on the western shores of the upper Volga. The names with the element Vilnear Finland probably derive from a Finnic personal name, but the same origin is improbable in the latter two areas.

The rule of thumb applied in this work is that the likelihood of names being of Finnic origin is high in those areas where there has presumably been a Finnic presence during the Middle Ages. Thus, the ethnic and linguistic history of Northwest Russia must be taken into consideration. Especially the studies of Rahkonen (2013) and Rjabinin (1997) have been important when solving the origins of Finnic-looking village names. For example, the village name Vylygalovo (MIN: 366) could be based on Finnic name element Vilja, but it is located around 200 kilometres southwest of the city of Novgorod, where signs of archaeological finds (Rjabinin 1997) and toponyms (Rahkonen 2013) that could be connected to Finnic tribes are limited. Thus, the name has not been chosen for this study. On the other hand, the village name Igaevo (MIN: 70) is included even if it is fairly far away from other Finnic village names, around 150 kilometres west of Novgorod. It is situated within the area that Rahkonen regards as having been inhabited by "Chuds" (2011: 248), and, in addition, a village called Čudkovo lies in the vicinity (MIN: 69). ${ }^{32}$

The villages are placed on the map in different ways. Most of the villages in Estonia and Finland are accurately situated according to the coordinates of the villages' current successors. The coordinates have been obtained from the National Land Survey of Finland and the Republic of Estonia Land Board (16 April 2018). Some of the villages no longer exist, but they can be placed on the map with good accuracy using leads from other sources. In Finland, for example, 16th-century taxation documents called fogderäkenskaper ('bailiff's accounts') present villages in geographical order. Villages located in the same area are also found in taxation documents near one another. Thus, the location of a place under investigation can be determined by figuring out the whereabouts of villages mentioned together with it in the taxation documents.

The villages in the Russian territory are placed on the map by hand. Villages situated in the areas that were part of the Kingdom of Sweden during the 17 th and 18 th centuries are easier to locate, because the old Swedish taxation documents and maps are well preserved (e.g. in the National

32. The meaning of the ethnonym Chud is still under discussion, but popular consensus is that it has been connected to the Finnic tribes living in Northwest Russia. See Grünthal 1997 for more details. 
Archives of Finland). Kepsu's manuscript (2010) has been very useful in determining the locations of these villages. In addition, two experts on Finnic toponyms in Northwest Russia, Denis Kuzmin and Irma Mullonen, have been helpful in working with some more problematic names.

Sometimes Russian villages could not be accurately located even using all of the above-mentioned sources. The editions of Russian documents, however, often give hints as to the whereabouts of villages. For example, it is possible to identify the neighbouring village or a natural landmark near the village under study. As stated earlier, village names in these documents frequently have descriptive additions. For example, the phrase Деревня на Галтеевп жъ островп Лембитово Сюдюне ('Village Lembitovo settlement on Galteev island') (POKV I: 416) reveals that a village containing the Finnic personal name element Lempi is located on an island called Galteev. Some of the village locations have remained unresolved despite all efforts. These places are located in the centre of their 16th-century pogost or 17 th-century Swedish parish.

Each village name is counted and placed on the map only once. It is not always simple to find out if a name mentioned in another village name refers to the same place or not. The Finnish (SA) and Estonian (KNR) sources are not problematic in this sense, because it is rather easy to notice if the same village name is mentioned several times. Russian sources, by contrast, are more difficult to comprehend, because one village name might be included in many other village names as well, e.g. Деревня Вилокала жъ ('village Vilokala also'), Деревня Новое въ Вилокаль ('New village in Vilokala'), Деревня Волосово в Вилокаль ('village Volosovo in Vilokala') and Деревня Вилокалажъ на озерг на Вилокалгь ('village Vilokala also at Lake Vilokala') (POKV II: 64-65).

As a rule of thumb, similarly written names or name elements in the same volost (part of a pogost 'parish') are considered one village name (as in the case of Вилокала ('Vilokala') above). Often the name phrase reveals the village location. There are, for example, two village names in Nikol'skij Ižorskij parish where the Finnic name element Kauko is found: Деревня Гавгуево въ Өоминг кониль ('Village Gavguevo in Fomin (end)') (POKV I: 358) and Деревня на Кавгуль на Лисинг ('Village Kavgula in Lisino') (POKV I: 422). Here, the name element Kauko clearly refers to two different locations, as Fomin is one of the islands on which the city of Saint Petersburg was built (Kepsu 1995: 41), whereas Lisino is a village approximately 80 kilometres southwest of Saint Petersburg. 
The next sections present the results of the study. Section 4 focuses on statistics and displays the collected names on a map, while Section 5 analyses the results in a broader historical and linguistic context.

\section{Results}

Altogether, there are 305 names collected from the sources mentioned in Section 2. More than half of the names (172) are from the area of the Diocese of Åbo. A total of 67 names come from Russian sources and the remainder (66) from Estonia. The high number of Finnish names is significant but, at least partly, it can be explained by the nature of the sources. As mentioned earlier, SA covers various kinds of documents from the $1560 \mathrm{os}$, whereas sources like NPK usually contain information from only one specific tax survey. Nevertheless, there are almost three times more Finnic village names in the Diocese of Åbo compared to the two other areas. This kind of difference cannot be explained by the heterogeneity of the sources alone. It must therefore be concluded that the pre-Christian Finnic personal name elements searched for in this study were used more frequently to name villages in the Diocese of Åbo than in Estonia or Northwest Russia.

\section{I. Collected names}

All of the names collected for this study are presented in the Appendix. Each village name is counted only once, as explained in the previous section. Because of limited space, only the following information is given about each name: the name of the village, the present-day municipality or administrative region and the source. The first column shows the names collected in alphabetical order. The second column presents the sources. The abbreviations used for the sources are explained in the references.

Due to the diversity of the research material, the village names are presented in various forms in the Appendix. Names collected from Suomen asutus 1560-luvulla (SA) are presented in the same way as they are in the book. Estonian village names are written according to the official practices of the Estonian Land Board (https://geoportaal.maaamet.ee/, accessed 16 April 2018) if possible. Otherwise, the oldest known form of the name is used. Russian names are presented in the same form as in the sources but transliterated using Latin letters according to the ISO 9 standard. Due to the lack of space, only the names are presented, meaning that locative 
descriptive additions, prepositions, postpositions and such are excluded. The nominative form of the name is presented whenever possible. Otherwise, the name is written as it is mentioned in the source. Names that have same form as in the original source material are written in italics. The letter $\check{e}$ (Б) is an old Cyrillic letter that in modern Russian writing has been replaced by the letter $e$ (e) in most cases.

As already stated in Section 3, all of the village names identified in the study are placed on the map and given coordinates. In the Appendix, the second column shows the contemporary municipality or administrative region where the village is located. Information concerning Estonian and Finnish villages has been obtained from the Republic of Estonia Land Board and the National Land Survey of Finland (16 April 2018). Officially, the names of Estonian municipalities include the expressions vald (English municipality or parish) or linn (city) (e.g. Raasiku vald). To save space, only the place names are displayed in the Appendix. Russian villages are listed according to their administrative regions (Russian район). The map of the administrative divisions in Russia was obtained from https://gadm.org/index.html (accessed 16 April 2019).

As the Appendix shows, most of the pre-Christian Finnic personal name elements chosen by Stoebke (see Section 1.2) are found in the research material. The only name elements not referenced are Joutsi and Kaikki. This is in line with Kepsu's list of pre-Christian Finnic personal names, which does not include these elements (2015a: 130). The most frequently used name element is Kauko, with 43 occurrences. ${ }^{33}$ In addition, the name elements Lempi (40), Iha (28), Vilja (24), Toivo (21) and Kirja (19) are common. In ten cases, the Finnic village names derive from preChristian complex names, for instance Iha-lempiä-lä (SA: 209). All but one of these instances occur in the Diocese of Åbo.

33. As stated in Section 2, some of the etymologies of chosen names are not completely certain, which means that the number occurrences of each name element is only an estimation. One must also note that a village name can consist of two different pre-Christian name elements, e.g. Kauko and Lempi in Kaukolempiälä (SA: 210). Both of these are included in the calculations. 


\subsection{The geographical spread of Finnic village names}

The round dots on Map 2 present the geographical distribution of Finnic village names. The star illustrates the location of Novgorod. The process of determining the precise locations of villages has been explained in Section 3, while the borders presented in the map were described in Section 1.2.

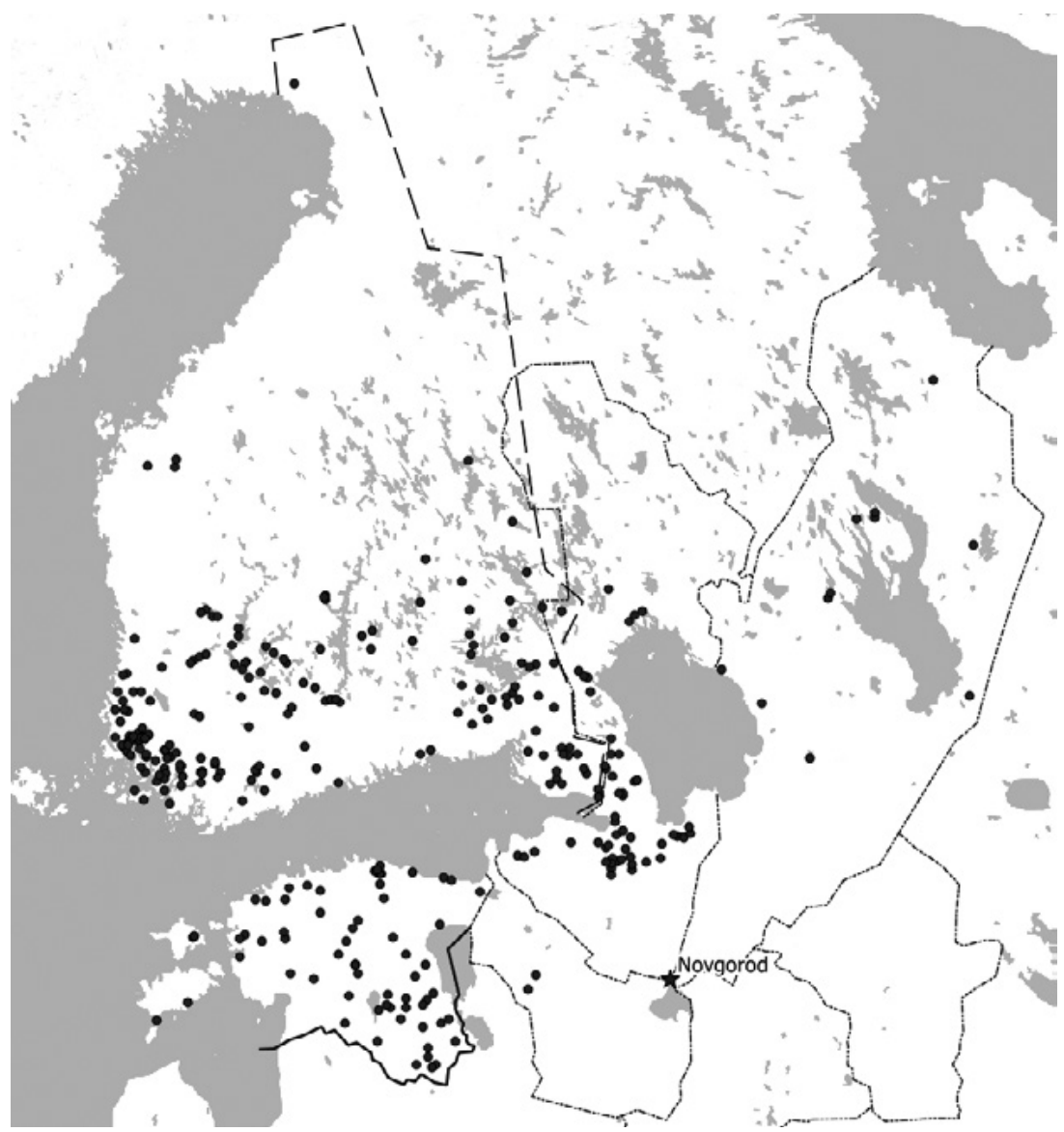

Map 2: The geographical distribution of village names based on preChristian Finnic personal name elements (map drawn by the author). Base map: Mapbox Basic Template. 
Most of the names are located close to the Gulf of Finland. The name elements under investigation occur most densely in Southwestern Finland and in the eastern end of the Gulf of Finland near present-day Saint Petersburg. Furthermore, many names occur in the old province of Häme (Swedish Tavastland), especially around Lake Vanajavesi. In addition, there are many names near the present-day Finnish-Russian border south of Lake Saimaa. The names on the Karelian Isthmus can be seen as a continuum of the ones in Eastern Finland. There are also many occurrences of the names in Estonia, especially in the northern parts and in the southeastern part.

\subsection{Areal differences in the spread of name elements}

Map 3 shows where the four most used name elements (Kauko, Lempi, Vilja and Iha) are found. The high number of Kauko names in southern Finland is notable (Map 4 presents these). Otherwise, there are no

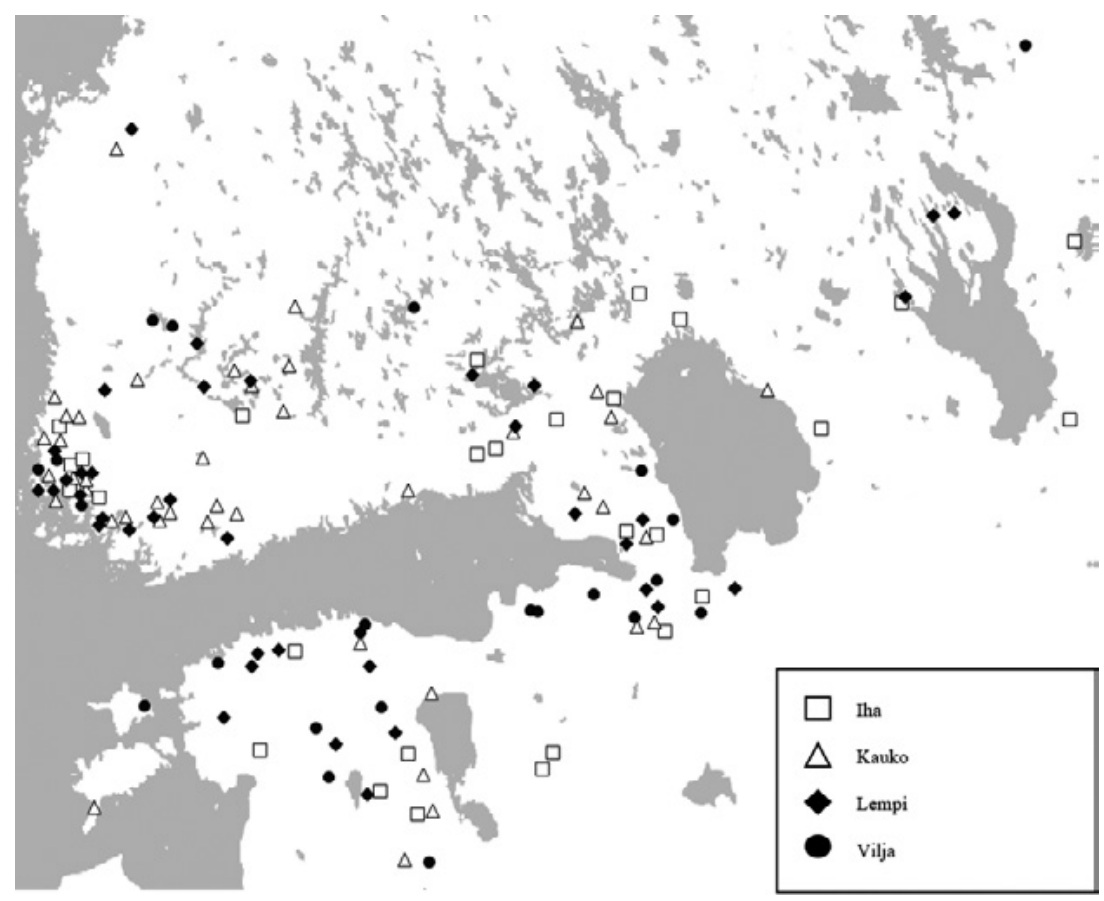

Map 3: The spread of the name elements Kauko, Lempi, Vilja and Iha (map drawn by the author). Base map: Mapbox Basic Template. 
significant differences in the distribution of these name elements. This is not a surprise, as a consistent distribution throughout the area was one of Stoebke's criteria for deciding whether a name element is Finnic or not. Nevertheless, the number of different names is too low to draw any proper conclusions about the areal differences in name use.

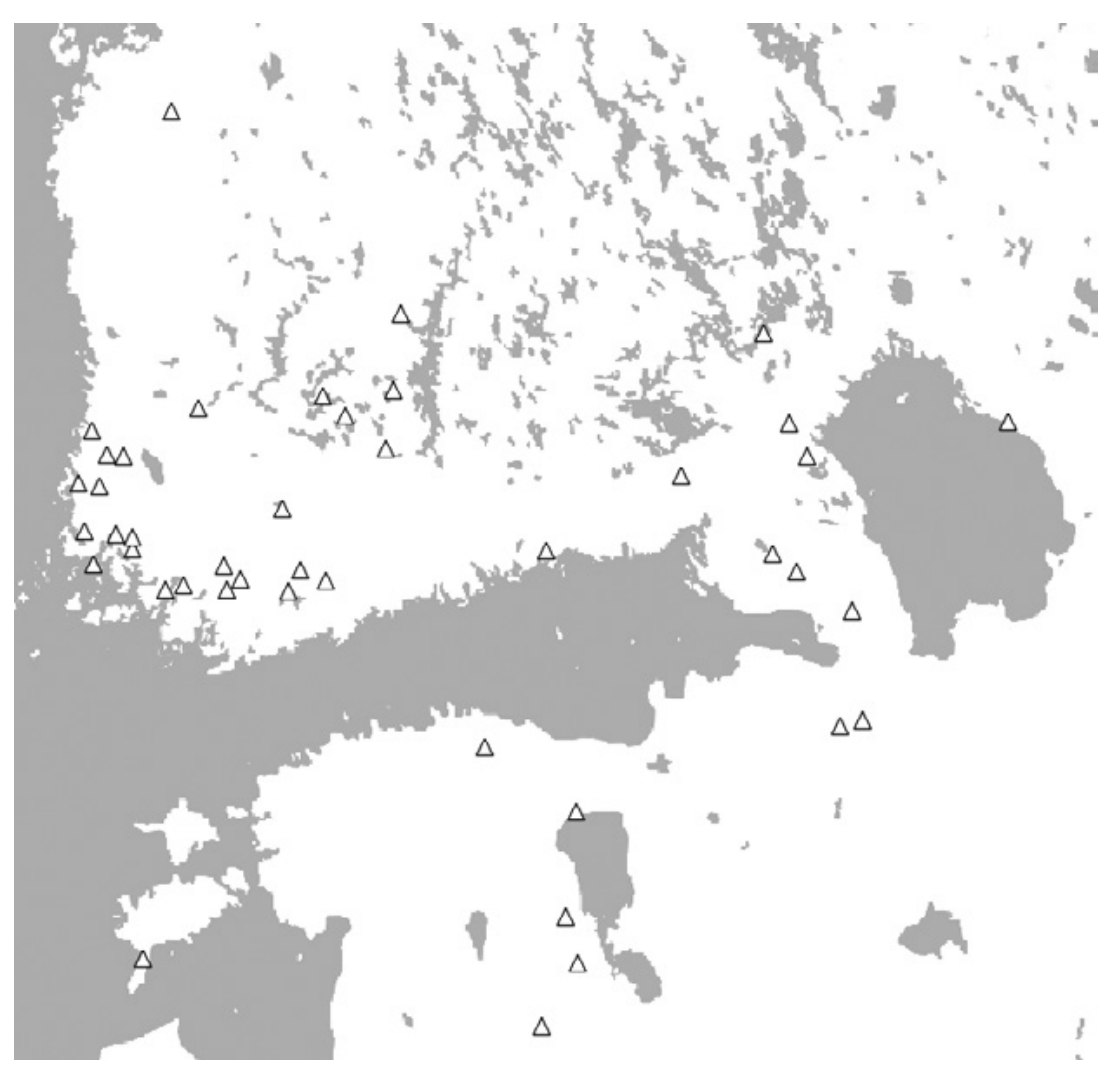

Map 4: The spread of name element Kauko (map drawn by the author). Base map: Mapbox Basic Template. 


\section{Discussion}

The aim of this article is not only to determine where Finnic village names were spread in the Middle Ages, but also to provide a broader overview of the historical development of Finnic anthroponyms and, simultaneously, to shed light on the history of Finnic tribes and languages. First, it is presumable that Map 2 shows areas that were populated by speakers of Finnic languages during the 15th and 16th centuries. The truth, however, is not that straightforward. Finnic people could have inhabited many other areas as well (cf. Frog \& Saarikivi 2015). Conversely, Russian or Swedish speaking inhabitants could have occupied villages with Finnic names. Nonetheless, Map 2 introduces many interesting perspectives on both Finnic personal names and the history of their users. Next, the most intriguing observations are discussed (Section 5.1), the geographical distribution of Finnic village names is compared to archaeological data (Section 5.2) and an overall picture of the spread of the Finnic village names is given (Section 5.3).

\section{I. Remarks on the geographical distribution of the Finnic village names}

Map 2 shows how Finnic village names are spread around the coastal areas of the Gulf of Finland. However, two areas have a surprisingly small number of village names based on pre-Christian Finnic personal names. First, the regions of Kymenlaakso (Swedish Kymmenedalen) and Uusimaa (Swedish Nyland) in southern Finland are visibly empty of these names. The reasons for this are presumably twofold. Traditionally, archaeologists have thought that the coastal areas of Kymenlaakso and Uusimaa were only sporadically inhabited in the later part of Iron Age (Raninen \& Wessman 2015: 354). This would explain the lack of village names derived from pre-Christian Finnic personal name elements. However, lately more and more Iron Age finds have been made in both areas (Jäppinen 2014; Wessman 2016). Thus, it is difficult to say how sparsely inhabited these areas really were.

The spread of Swedish settlers to the area from the 13th century onwards is another explanation for the lack of Finnic village names. The Swedish-speaking population superseded the Finns and, accordingly, most of the settlement names mentioned in the 16th century are Swedish ones (cf. FSBN). It is still noteworthy that, in both areas, there is a significant number of old village names that are clearly of Finnish origin, but very few of these derive from pre-Christian Finnic personal name elements 
(cf. FSBN; Kepsu 2005; Raunamaa 2017). This again implies that Finnic settlements in the regions of Kymenlaakso and Uusimaa were rather sparse and maybe also new.

Western Ingria, or the area of Votes, is another area that is surprisingly lacking in Finnic village names. Personal names and settlement names in the edition of the 16th-century census book (NPK III) indicate that this area has been populated by Finnic speakers. Especially the parishes bordering the Baltic Sea (Toldožskij v Čjude, Kargal'skij and Pokrovskij Djatelinskij) have many anthroponyms that are based on the studied Finnic personal name elements. However, only a few village names are derived from the same elements. Map 5 (below) presents the approximate borders of these parishes as they were in the 16th century, and the number of peasants with Finnic personal names in the research material (POKV I-II, NPK III, IV). ${ }^{34}$ In addition, the locations of the Finnic village names are displayed on the map.

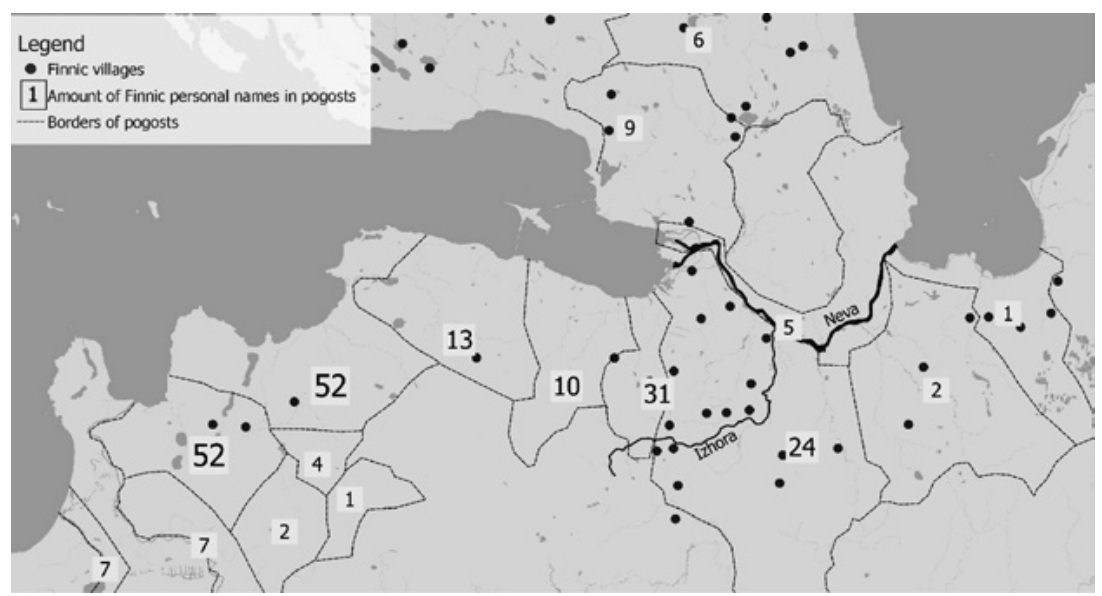

Map 5: Pogosts in Ingria and number of pre-Christian Finnic personal names mentioned in 16 th-century documents. The chosen personal names are based on the same 22 pre-Christian Finnic name elements that are used in this study. Map drawn by the author. Base map: Mapbox Basic Template.

34. In addition to the parishes in the northern parts of Vodskaja pjatina, preChristian Finnic personal names were found near the city of Ivangorod in Šelonskaja pjatina (NPK IV). The northernmost areas of Šelonskaja pjatina would probably have more references to Finnic personal names, but this area is only sporadically presented in NPK IV. 
The lack of Finnic village names can be explained in part by the naming conventions used by the scribes. For example, in Kargal'skij parish, most of the village names are descriptive and simple in structure, such as Д. другая Копаница на Систи ('(village) second Kopanica at the River Sisti') and Д. третья Копанииа на Систи ('(village) third Kopanica at the River Sisti') (NPK III: 501-502). As mentioned earlier, the designated scribes did not necessarily visit all the villages but instead used local informants. Moreover, the above-mentioned parishes were border regions and located far from Novgorod. On the other hand, it is possible that the incongruity between the number of Finnic village names and Finnic personal names in Western Ingria is evidence of a rather late migration wave that probably came from the direction of Estonia, where pre-Christian personal names prevailed well until the 15th century (Roos 1976: 106). Moreover, the Estonian and Votic languages are closely related to one another (Kallio 2014: 62).

A third area that unexpectedly lacks Finnic village names is the region east and southeast of Lake Ladoga. It is an area that has had a strong Finnic population (Karelians, Ludes and Vepsians) all the way up to the 2oth century (Frog \& Saarikivi 2015). In addition, there are many other place names in the area that are of Finnic origin (Mullonen 2008). Especially interesting are those settlement names that include the suffix -l: e.g. Hodrilskoe ( ${ }^{\star}$ Huotari-la) and Kurgilovskaja $\left({ }^{\star}\right.$ Kurhi-la $/{ }^{\star}$ Kurgi-la) (Mullonen 2008: 185; PKOP). This suffix is derived from the Finnic locational suffix $-l A$, which is, as mentioned earlier, frequently used in cases where the name is based on an anthroponym. The census books of 1496 and 1563 indicate that Finnic personal name elements (e.g. Koku-ev, Melgu-ev and Rahko-ev) were used in the area, as were the suffixes -oi/-ui, which are considered Finnic (Mullonen 2008: 157-159; PKOP).

\subsection{The spread of Finnic village names compared to archaeological data}

This section presents a comparison between the spread of Finnic village names and archaeological sites in the area under investigation. The aim was to produce a map that, based on the archaeological data, demonstrates the settlement situation at the beginning of the second millennium. The result is presented in Map 6. Areas that were probably inhabited at the end of the Iron Age are marked in grey. 


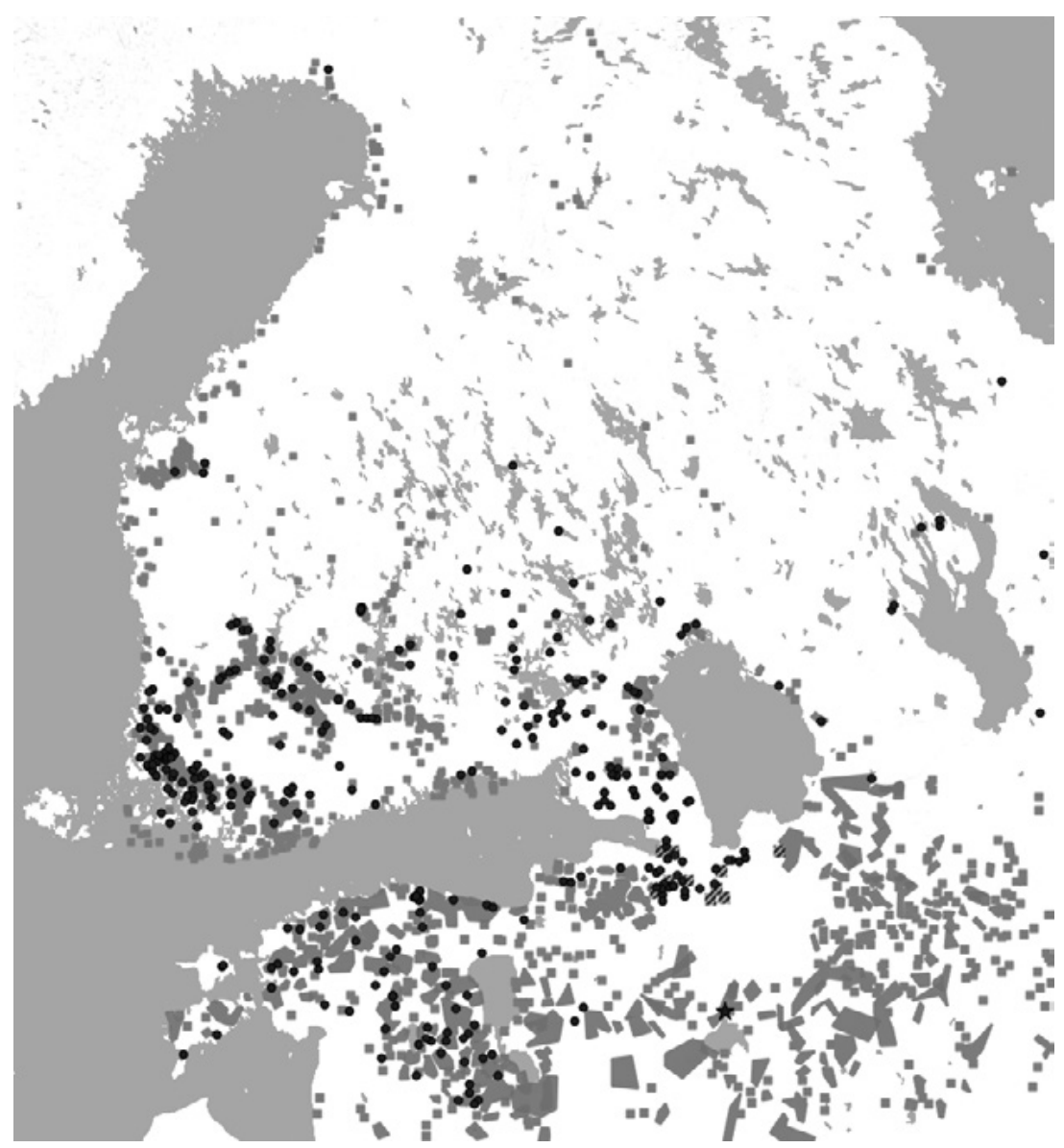

Map 6: Finnic village names (as dots) and archaeological sites (in grey) from the Late Iron Age (map drawn by the author). The oblique lines depict the so-called Finnic graves dated to the 12-14th centuries. The star shows the location of Novgorod. See the body text for more information about the map. Base map: Mapbox Basic Template.

It must be emphasised that the results of the study are only indicative. There are many problems when gathering archaeological data from such a large area. One of the biggest issues is that some regions are better studied than others are. Furthermore, ancient cultures differed in their customs. Some tribes buried their dead with metal weapons and ornaments in big graves made of stones that are still visible, whereas others might do it in such a way that no signs of graves have survived to this day. In addition, as 
indicated in Section 5.1, new finds are continuously being made and, consequently, the picture of Late Iron Age settlement in the northern Baltic Sea area may change in the future.

The finds from Finland are based on the Ancient Relics Register (Muinaisjäännösrekisteri). Of these, only those Iron Age finds connected to permanent settlements (cemeteries and dwelling sites) are included. ${ }^{35}$ There is no division between the different periods of the Iron Age (500 BC - AD 1150) in the register, which is problematic. Nonetheless, the result is in line with other depictions of Late Iron Age settlements (cf. Raninen \& Wessman 2015: 299).

The map of the Late Iron Age dwelling sites in Estonia is based on Kriiska \& Tvauri (2007: 173). The settlement situation in the ceded area of Karelia is depicted according to Uino (2003: 350). Again, only finds connected to permanent settlement have been included.

The depiction of the settlement situation in Northwest Russia is more problematic. There are no comprehensive sources presenting the Late Iron Age finds in this area. Thus, the result shown in Map 6 is a compilation of many separate studies, which partly overlap and partly contradict each other. In addition, the studies do not always cover the desired period. For example, one study might present graves dated to the seventh and eighth centuries, but it does not necessarily cover later periods. In cases like this, the assumption has been made that the settlement situation has remained unchanged until the Middle Ages.

The Late Iron Age cemetery finds near the city of Novgorod (c. 100-150 $\mathrm{km}$ radius) and in the Bežetskaja fifth are based on a study by Sedov (1982: 60) (for the locations of the different fifths, or pjatinas, see Map 1 above). The same study (1982:167) is also the source of the finds in the area east of Lake Peipus, which covers most of the western parts of the Šelonskaja fifth. The finds in Ingria are based on work by Rjabinin (1997: 17, 19), as are the finds in areas southeast of Lake Ladoga (ibid. 90, 97). The settlement situation in the regions of Lake Onega and Lake Beloye is based on work by Makarov (1997: 82). Since the lower parts of the Neva Estuary and the nearby areas are surprisingly empty of archaeological sites dated to the Late Iron Age, Map 6 also depicts the spread of early medieval cemeteries (AD 1100-1400) in this region (Sorokin 2008: 90-91). These are marked with oblique lines.

35. Here, the expression "permanent settlement" denotes a homestead or village that was inhabited year-round and was used from one generation to another. 
The comparison between the spread of Finnic village names and the settlement situation in the area under investigation reveals many interesting findings. First of all, it can be noted that these two often overlap. In other words, Finnic village names occur near the areas that were probably inhabited at the turn of the first millennium. This applies especially to the areas in Estonia and Western Finland.

However, the picture is slightly different in Northwest Russia, including Karelia. Especially interesting are the southern and western parts of the Karelian Isthmus and the areas near the River Neva. Many Finnic village names are found there. This is not surprising, because the area has been inhabited by Finnic speakers (cf. Uino 1991, 2003; Sorokin 2008). However, it is intriguing that there are not many signs of Late Iron Age settlements in the area.

Only a few Late Iron Age finds have been made in the western part of the Karelian Isthmus (Uino 2003: 487). It has been assumed that the area was inhabited primarily during the 13th century (ibid. 486; Kepsu 2018: $166,516)$. At the basin of the River Neva, the oldest signs of Late Iron Age pagan cemeteries are from the 12th century, and these have been considered Finnic or Izhorian (Sorokin 2008: 88-91, 122-123). The easternmost long barrow cemeteries (kurgans) located on the Izhora Plateau, which have been associated with the Slavic expansion (Sedov 1995), are not far away from the Finnic villages found near the upper reaches of the River Izhora. The oldest long barrow cemeteries on the plateau are from the tenth century (Uino 1991: 22). In addition, the oldest cemeteries that are considered Votic or Izhorian in the coastal areas of Ingria are dated to the 12th century at the earliest (ibid. 21-32).

The lack of Iron Age cemeteries in the eastern parts of Gulf of Finland can be partly explained by the lack of research and the outdated sources. It still cannot be overlooked that this area seems to be less populated than and culturally different from the northern Karelian Isthmus or lower Volkhov area, for example. All in all, the geographical distribution of Finnic village names is connected to the development of the Finnic languages and tribes. With this in mind, the next section, which concentrates on explaining the spread of Finnic village names, also presents an attempt to describe the historical and linguistic developments that occurred in the Baltic Sea region during the latter half of the Iron Age (approximately 700-1200). 


\subsection{The development and spread of Finnic pre-Christian personal names in the light of archaeology and linguistics}

As we are mostly speaking about the period at the turn of prehistoric and historic times, the number of written sources is limited. Despite this, there are some archaeological and linguistic assumptions that can serve as guidelines when attempting to describe the development and spread of Finnic tribes, languages and pre-Christian personal names.

First of all, it must be admitted that discerning the age of the pre-Christian Finnic personal name system with current sources is an impossible task. Only limited estimations can be made based on overall knowledge of pre-Christian anthroponymic systems and general assumptions about the history of the Finno-Ugric languages. Most modern linguists date the arrival of Finno-Ugric languages in the Baltic Sea area to centuries before our era. For example, Valter Lang (2018: 263) concludes that the arrival of Finno-Ugric languages should be placed in the Bronze Age (1700-500 BC). Accordingly, we could place these Bronze Age centuries as the terminus post quem for the pre-Christian Finnic anthroponyms. In addition, it should be noted that the Finnic personal name system has differed from those of other Finno-Ugric speakers, such as Mari and Mordvins (Nissilä 1965: 84). It seems that Finnic speakers adopted a new kind of personal name system after the divergence of their language.

Of the European pre-Christian personal name systems, one of the best known is the Ancient Roman one, which existed for many centuries from about $700 \mathrm{BC}$ onwards. Various things changed in the naming culture during its existence, but many aspects also remained (Salway 1994). Regarding Finnic naming conventions, Old Germanic personal names are more suitable references, because their bearers (Scandinavians) were living near Finnic areas. Ernst Förstemann's survey of Old German (Altdeutsche) personal names contains mainly names from Central Europe and excludes Old Norse names (1856: VI). ${ }^{36}$ The Scandinavian runic-text database (Scandinavian Runic-text Database), in turn, allows the user to search for personal names that are attested on runestones and are dated to the Old Norse

36. Förstemann has included names that are older than $\mathrm{AD} 1100$ in his study. The names were collected among various Germanic tribes (Alemanni, Bavarians, Burgundians, Goths, Franks, Frisians, Langobardi, Saxons, Thuringii and Vandals). 
era (about AD 900-1200). The comparison of these two sources indicates that the Scandinavian personal names were in various ways similar to the ones used by other Germanic speakers, but also in many ways different. For example, some Scandinavian name stems (such as Birgin) seem to be missing from Förstemann's list of Old German names and vice-versa (e.g. Amal-). Nevertheless, it is safe to say that the pre-Christian Germanic personal name system remained fundamentally the same for centuries.

Both Ancient Roman and Germanic naming cultures, however, started to change substantially when Christianity gained its foothold (Ainiala et al. 2012: 149-152; Salway 1994: 124). Connected to this, Salway argues that most of the major transformations of Ancient Roman naming culture coincide with the most tremendous political and social changes (1994: 144). Salway's argument can also be applied to other naming cultures. In addition, this is in line with the common perception of the nature of personal names. It is known that personal names are closely connected to the culture around them (cf. Ainiala et al. 2012: 136-137) and, moreover, that they are more prone to change than other lexical elements (Peterson 1994: 159).

To sum up, there is no way to know how far back in history the use of pre-Christian Finnic personal names dates, but we can assume that the development of this naming system is connected to some major social and cultural changes that occurred in the northern Baltic Sea area during the prehistoric era. It is as very likely that the Finnic naming culture has gone through various changes since the predecessors of this language group arrived in the Baltic Sea area during the Bronze Age. Due to these problems, it is better to concentrate on questions of how the village names based on pre-Christian Finnic name elements had spread to the areas seen in Map 2 before the end of the 16th century and leave the origins of pre-Christian Finnic naming culture as a secondary topic.

Regarding the merge and spread of Finnic personal names, the midpoint of the first millennium AD is a sufficient period to start. At that time, Northern Europe was still in turmoil, but it was starting to recover from the effects of the Migration Period. The middle of the first millennium was also a time when Estonia and Western Finland were in close connection with the Scandinavians (Kriiska \& Tvauri 2007: 160-187; Raninen \& Wessman 2015: 263-269). In addition, there were contacts with the Baltic tribes (e.g. Kriiska \& Tvauri 2007: 184; Raninen \& Wessman 2015: 269-270). From the eighth century onwards, at the latest, the Scandinavians were influencing the eastern parts of the Gulf of Finland, as probably were the 
Slavic tribes (CHR: 47-72; Kallio 2006). ${ }^{37}$ It can be assumed that these connections with neighbouring cultures would have affected the language(s) spoken by Finnic people. Germanic loanwords borrowed into the Finnic languages or dialects spoken near the Gulf of Finland (Gulf of Finland Finnic) are a good example of this (cf. Schalin 2018: 67), as is the Christian vocabulary of Slavic origin that is widespread in Finnic languages (Kallio 2006: 156-157). Accordingly, the Finnic personal name system was probably influenced as well. Viljo Nissilä (1965: 87-88) has argued that that the two-part type of Finnic personal names (e.g. Kauko-valta) is of Germanic origin.

The second half of the first millennium was a period of growth in Estonia and Western Finland. Both areas were developing economically and culturally. Weapons, coin hoards, ornaments and other archaeological finds are a good example of this. Especially Northern Estonia can be seen as an innovative centre of the Gulf of Finland region during those centuries. In addition, the introduction of a new kind of plough made it possible to cultivate lands of heavy and clayey soil, and thus, new settlements could be established. Fortified hillforts serve as proof of social development, as workforce was needed for the construction and maintenance of these defences. (Kriiska \& Tvauri 2007: 165-187; Raninen \& Wessman 2015: 316.)

Considering the above, it is understandable that developing areas in Estonia and Western Finland started to spread their influence into the neighbouring areas. These impacts could also explain the distribution of Finnic village names. Northern Estonia had close connections, for example, with Western Ingria (Frog \& Saarikivi 2015: 87; Stasjuk 2013), whereas archaeological finds in Karelia and Eastern Finland show influence from Western Finland, most likely from Varsinais-Suomi and Häme (Hiekkanen 2003: 486; Uino 2003: 349-353). Moreover, before the end of the 12th century, the Karelian ethnos was already archaeologically distinct. The northwest coast of Ladoga had become a centre from which the Karelian culture started to spread (Saksa et al. 2003: 385). At the beginning of the second millennium, Karelian influences, and probably their naming culture as well, were extending in many directions, for example towards Eastern Finland (Raninen \& Wessman 2015: 358), to the eastern shores of the Gulf of Bothnia (Vahtola 1980: 315-391) and towards Northwest Karelia (Kuzmin 2014a: 76).

37. On the other hand, Kriiska \& Tvauri (2007: 170) claim that there is no evidence of Slavic people in the area of Novgorod before the tenth century. 
Ancient Karelian culture was also present in the western parts of the Karelian Isthmus and on the eastern shores of Lake Saimaa (Hiekkanen 2003: 485-486).

Karelian influence is evident in Ingria as well, but the level of this connection has been much debated by archaeologists and linguists (cf. Saksa et al. 2003: 447). Despite the lack of consensus, it seems obvious that, at least linguistically, the Karelians have had an effect on the Izhorian(s) (Frog \& Saarikivi 2015: 89). The spread of Karelian culture and naming conventions from the 12th century onwards could also explain the presence of Finnic village names in the eastern parts of Ingria near the rivers Neva and Izhora, as seen in Map 2 and Map 5. This, in turn, is in line with the earlier observation that the earliest Late Iron Age (and pre-Christian) cemeteries found in these areas are dated to the 12th century (Sorokin 2008: 122-123). Thus, it could be assumed that the Finnic presence in the eastern parts of Ingria dates to the same century.

However, the truth is not that simple. It seems obvious that at least at some point during the Iron Age, Finno-Ugric people have inhabited Ingria. Many linguists believe that Finnic speakers or their predecessors have lived in or passed through the area during prehistorical times (e.g. Janhunen 2009: 210; Saarikivi \& Grünthal 2005: 136). Similarly, Pauli Rahkonen (2013: 241) suggests that Ingria would have been Finnic territory during the Iron Age (AD 1-80o). His suggestion is mainly based on his studies of hydronyms in Northwest Russia.

All things considered, Ingria and especially its eastern parts (the River Neva region) had very little Iron Age activity before the 12th century according to current archaeological data. This does not mean that the region was completely devoid of human presence. Although some areas are swampy and of poor quality for agriculture, the local soil mostly consists of sandy marl and silt, which should have been suitable for Late Iron Age cultivation (Peruskartasto: 9; Raninen \& Wessman 2015: 265; ToikkaKarvonen 1990: 168).

The lack of Iron Age graves in Eastern Ingria can be explained by the local burial customs. It is possible that the dead were buried in such a way that no signs of the graves have survived in modern times (cf. Raninen \& Wessman 2015: 309). In addition, Eastern Ingria was very much in the middle of Late Iron Age trading networks. As it is known, the rivers Neva and Volhov were important waterways for trade and transportation during the Iron Age. At least from the eighth century onwards, Scandinavians were 
active in this region and had an impact on the establishment of important commercial and political centres, such as Staraja Ladoga and Novgorod (Frog \& Saarikivi 2015: 72, 76, 78; Kriiska \& Tvauri 2007: 168-169). However, the foreign presence did not have only positive effects. Scandinavian Vikings and other aggressive looters have been suggested as one of the reasons for the lack of Iron Age settlement in the coastal areas in Northern Estonia and Southern Finland (Huurre 1995: 158). Even if this reason is disputable, it is still something that could explain why so few Iron Age finds have been made in the River Neva region.

To conclude, it is difficult to know how and when Ingria and especially its eastern parts were inhabited during the Iron Age. Still, an interesting question is whether people that could be called Finnic inhabited the River Neva region before the 12th century. In the light of current knowledge, there are many archaeological sites dated to the Iron Age in neighbouring Finnic areas, such as Northeast Estonia or the western shores of Lake Ladoga. This seems to indicate that the presence of Finnic tribes is archaeologically visible. Accordingly, it can be claimed that those regions in Ingria where there are no archaeological sites dated to the Viking Age were at least culturally different from the neighbouring Finnic areas. This would support the idea that the eastern parts of Ingria underwent strong Finnic influence during the last decades of the Iron Age, which led to the emergence of so-called Finnic or Izhorian graves from the 12th century onwards (Sorokin 2008: 122-123)..$^{8}$

This line of thought is supported by Valter Lang's recent study, where he attempts to create a cohesive picture of the formation and development of the Finnic culture and language. Lang suggests that Ingria was not a part of the first wave of Finnic expansion, which emerged in coastal Estonia and Finland around the ninth century BC (2018: 215, 308-311). Based on archaeology and linguistics, he concludes that the emergence of Izhorian culture was the result of Karelian influences, which had started relatively late, probably during the 12th century (ibid. 256). ${ }^{39}$ Presumably, these

38. That said, it is questionable whether the emergence of so-called Finnic or Izhorian graves can be described as strong on the basis of current archaelogical data. There are six burial sites in Eastern Ingria that are considered Finnic ones (Sorokin 2008: 90-91).

39. A noteworthy remark is that according to archaeologist Olga Kon'kova (2008: 11-21), many of the old gravesites (dated to the 11th-17th centuries AD) in Western Ingria cannot be considered Votic or Slavic, and must therefore be of 
contacts occurred near the rivers Neva and Izhora from which, according to Lang, the Izhorians also originate (ibid.). In addition, a good example of Karelian influence is the ethnonym karielaizet ('Karelians') that some Izhorians have used to refer to themselves (Frog \& Saarikivi 2015: 89)..$^{4}$

Lang's study covers the origins of Vepsians as well. Traditionally, the area to the southeast of Lake Ladoga has been considered the place of origin of the Vepsians (Frog \& Saarikivi 2015: 91; Kuzmin 2014b: 287). As seen on Map 2, this is also an area that is almost entirely lacking in Finnic village names. Many archaeologists and linguists have suggested that the emerge of a special kind of grave mounds (sopkas) at the end of the first millennium AD in the area southeast of Ladoga can be connected to the Vepsians (Frog \& Saarikivi 2015: 91; Lang 2018: 257). However, Lang (2018: 257) claims that there are almost no signs of Finnic influence based on the ceramics in the "Vepsian" grave mounds. Furthermore, he suggests that those who buried their dead in grave mounds on the south-eastern coast of Ladoga were indigenous people who only later, as a result of Karelian influence, became linguistically and culturally Finnic. This development is supported by the local place names, of which many are non-Finnic or non-Slavic in origin (ibid.). There are, for example, hydronyms such as Kalarjärv, Padarjärv and Syvärjärv that contain the element -ar-/-är-, which probably derives from the generic part *järi ('lake'). It seems that at some point in (pre)history, local name users no longer understood this and, accordingly, another generic part with the same meaning (-järv) was added (Rahkonen 2011: 219). The lack of Finnic village names in the area would be in line with the assumption that the Vepsian culture became

Izhorian origin. On the other hand, Kon'kova claims that many of the objects found in the graves are comparable to both Russian and Votic culture. In addition to that, there are no signs of Karelian funerary inventory (2008: 22-27). This is in line with the suggestion presented by linguists that there are some old substrate features in the Western Izhorian dialects that are not found in the eastern ones (Lang 2018: 257).

40. These chapters focus on the linguistic and cultural history of Eastern Ingria, but many of the issues discussed are also relevant to the western parts of the Karelian Isthmus, which is another area where many Finnic village names are located but only very few signs of Late Iron Age activity have been found (Uino 2003: 487). An interesting remark is that, according to some linguists (e.g. Leskinen 1991), the Karelian dialect spoken on the western Karelian Isthmus is closely related to Izhorian or has even developed from it. Nevertheless, this topic requires a more thorough review than what can be provided here. 
Finnic only later, probably after the use of pre-Christian personal names was already in decline. At the very least, it means that the convention of naming villages after pre-Christian Finnic personal names did not spread among the Vepsians as it had spread to the western part of the Karelian Isthmus and Eastern Ingria.

\section{Conclusions}

The aim of this article was to study where the village names based on preChristian Finnic anthroponyms had spread by the end of the 16th century. The results shed light on many aspects of the usage of pre-Christian Finnic personal names. In addition, the spread of Finnic village names was compared to the results of archaeological and linguistic research in order to gain a better understanding of the development of the pre-Christian Finnic personal name system.

Despite the problems with the quality of different source materials, altogether 305 village names were collected based on the pre-Christian Finnic personal names. The most common pre-Christian name elements are Kauko (44 instances), Lempi (42), Iha (28), Vilja (24), Toivo (20) and Kirja (19). Due to the number of collected names, it was difficult to study regional differences in the usage of the names. Only the Kauko names have a distribution that could be considered a specific one. These names are mainly located in Western Finland (cf. Kepsu 2018: 35).

A wide range of conclusions can be drawn based on the geographical distribution of Finnic anthroponyms (Map 2). This map presents the areas where a certain Finnic naming convention had spread by the 16th century. The map is in line with other descriptions of the topic, for instance Kepsu (2015a) and Saarikivi (2017). Their studies include modern village names as well, and, accordingly, this explains why they have found more names in Northern Fennoscandia and Northern Russia.

Map 2 shows that the core areas of Finnic village names are in Estonia, Western Finland, Eastern Finland including the Karelian Isthmus and Eastern Ingria. These are all areas inhabited by Finnic tribes before the 14th century (cf. Frog \& Saarikivi 2015). As Map 5 indicates, the Finnic village names occur in Estonia and Western Finland in areas that were densely inhabited before the end of the first millennium AD, whereas the two more eastern concentrations of names are located in areas that do not show signs of significant Late Iron Age settlements. 
Eastern Ingria becomes archaeologically visible only from the 12th century onwards, when the use of so-called Finnic or Izhorian graves began (Sorokin 2008: 122-123). It is conceivable that Finnic village names were spreading to the area simultaneously. Nevertheless, this does not mean that Eastern Ingria could not have been inhabited by Finno-Ugric tribes earlier. Rather, it signifies that Eastern Ingria underwent remarkable influences from the neighbouring Finnic areas after the turn of the second millennium AD. It seems that the western parts of the Karelian Isthmus and Eastern Finland were similarly part of the late spread of Finnic culture. These impacts were probably caused by Karelians who were active in the eastern parts of Gulf of Finland from the Viking Age onwards (Lang 2018: 254-258; Saksa et al. 2003: 383-474; Uino 2003: 381-382). Karelian influence spread also towards the north and east. For example, in the area known as White Sea Karelia (Finnish Vienan Karjala), local folklore and place names demonstrate how strong these impacts have been (Kuzmin 2014a). Similarly, based on linguistics and onomastics, it is likely that the area inhabited by Vepsians in the southeast coast of Ladoga were influenced by the Karelians (Lang 2018: 257, 316). These two areas have, however, only a few Finnic village names compared to Eastern Ingria, Eastern Finland and the Karelian Isthmus. ${ }^{41}$ Therefore, it can be concluded that the spread of Finnic culture among the predecessors of Vepsians and White Sea Karelians was at least somewhat different from what it was in the areas south and west of Ladoga.

All in all, it seems that the pre-Christian Finnic naming conventions originated in the western parts of Gulf of Finland, from which they spread eastwards. Estonia and Western Finland were areas that were developing quickly, both culturally and economically, during the second half of the first millennium. These were also the areas that had extensive contacts with the neighbouring tribes, for instance Scandinavians and Slavs. It is possible that these contacts influenced the personal name system used by Finnic people as well.

The cultural and economic upswing in Estonia and Western Finland made it possible for cultural and linguistic innovations, probably together

41. Most of the Vepsian territory and parts of White Sea Karelia are covered in the census book PKOP. The southern coast of the White Sea is covered in the census book compiled by Solovetsky Monastery (ASM), whose index of names was analysed in search of Finnic village names. 
with settlers, to spread into new areas, especially to the east. This impact, however, did not spread rapidly throughout the northern Baltic Sea area but rather gradually from the central areas to the periphery. Western Finnic influence was one of the reasons why, at the turn of the second millennium, Karelian culture emerged on the western coast of Ladoga. Karelians were probably the ones who continued to spread Finnic pre-Christian personal name elements into the surrounding areas including Eastern Ingria and the western parts of the Karelian Isthmus.

It seems obvious that the usage of pre-Christian Finnic personal name elements began to decline after Christianity gained a permanent foothold. Foreign political actors, such as the Kingdom of Sweden, the Novgorod Republic and the Teutonic Order, accompanied the spread of Christianity into the area inhabited by Finnic people. These cultural, political and social changes must have influenced the naming conventions as well. Areal and temporal differences are naturally also significant, but from a broader perspective, it seems that the usage of pre-Christian Finnic personal name elements started to decline first in the western parts of Gulf of Finland area and later in the east. For example, only a few Finnic village names occur in the northern parts of Central Finland and Northern Savo, which were inhabited by Savonians mainly during the 16th and 17th centuries (Raunamaa 2019; SAK; Vahtola 2003: 55-57)..$^{42}$ Apparently, the use of pre-Christian Finnic anthroponyms was already declining among the settlers.

This study sheds light on the history of pre-Christian Finnic personal names in many ways. Nevertheless, many questions still remain to be answered. For example, it would be intriguing to create a distribution map of all the pre-Christian Finnic personal names attested in old documents. Computational methods would facilitate this kind of research, especially now that many editions of old documents are being converted into digital formats. Similarly, it would be fruitful to broaden the area of this kind of study. Many interesting names could occur, for example, in old documents concerning areas of the Pskov Republic and the Lake Beloye region.

42. The Savonians are a Finnish tribe originating in Southern Savo. They inhabited many regions mainly in the eastern parts of Finland (Pirinen 1982). 


\section{Distribution of village names}

\section{References}

Ainiala, Terhi \& SaArelma, Minna \& Sjöblom, Paula. 2012. Names in focus: An introduction to Finnish onomastics (Studia Fennica Linguistica 17). Helsinki: Finnish Literature Society. https://doi.org/10.21435/sflin.17

Alanen, Timo. 2004. Someron ja Tammelan vanhin asutusnimistö: Nimistön vakiintumisen aika. Somero: Amanita. (Doctoral dissertation.)

ASM = Либерзон, И. 3. 1988. Акты социально-экономической истории Севера России кониа XV-XVI в. Акты Соловецкого монастыря 1479-1571 22. Археографическое введение. Ленинград: Наука.

BRINK,STEFAN. 2016. Transferred namesand analogyin name-formation. In Hough, Carole (ed.), The Oxford handbook of names and naming, 158-166. Oxford: Oxford University Press. https://doi.org/10.1093/oxfordhb/9780199656431.013.43

CHR = Perrie, MaUreen (ed.). 2006. The Cambridge history of Russia: Volume 1. From early Rus' to 1689. Cambridge: Cambridge University Press.

https://doi.org/10.1017/CHOL9780521812276

CHS = Helle, Knut (ed.). 2003. The Cambridge history of Scandinavia: Vol. 1, Prehistory to 1520. Cambridge: Cambridge University Press.

https://doi.org/10.1017/chol9780521472999

FMU = Finlands medeltidsurkunder, 1910-1924. Samlade och i tryck utgifna af Finlands statsarkiv genom Reinhold Hausen. Helsingfors: Statsarkivet. 1924.

Forsman, A. V. 1894. Tutkimuksia suomen kansan persoonallisen nimistön alalla 1. Helsinki: Suomalaisen Kirjallisuuden Seura.

Förstemann, ERnst. 1856. Altdeutsches namenbuch: Erster band. Personennamen. Nordhausen: Verlag von Ferd. Förstemann.

Frog \& SAARIKIVI, Janne. 2015. De situ linguarum fennicarum aetatis ferreae, Pars I. RMN Newsletter 9. 64-115

FSBN = Finlandssvenska bebyggelsenamn. Sammanställd av Lars Huldén m.fl. Svenska litteratursällskapet i Finland r.f. http://bebyggelsenamn.sls.fi (Accessed: 1 November 2018.)

Gottlund, C. A. 1872. Allmogens uti Savolax och Karelen finska familjenamn: Betraktade $i$ historiskt och arkeologiskt afseende. Helsinki: Suomalaisen Kirjallisuuden Seura.

GRÜNTHAL, RiHo. 1997. Livvistä liiviin: Itämerensuomalaiset etnonyymit. Helsinki: Helsingin yliopisto \& Suomalais-Ugrilainen Seura.

Hausen, Greta. 1924. Nylands ortnamn: Deras former och förekomst till år 1600. Helsingfors: Svenska litteratursällskapet i Finland.

HiekKANEn, MARKus. 2003. Viipurin lääni - rautakaudesta keskiaikaan. In Saarnisto, Matti (ed.), Viipurin läänin historia I: Karjalan synty, 475-504. Lappeenranta: Karjalan kirjapaino.

Hudrre, Matti. 1995. 9000 Vuotta Suomen esihistoriaa. Helsinki: Otava.

JANHunen, Juha. 2009. Some additional notes on the macrohydronyms of the Ladoga region. Studia Etymologica Cracoviensia 14. 203-212.

JÄPPINEN, JoUNI. 2014. Rautakymi: Harrastajatutkimuksen tuloksia. SKAS

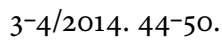


Johansen, Paul. 1938. Bruchstücke des Landbuches der Ordensmeister für Rujen und Helmet. Beiträge zur Kunde Estlands 21. 43-61.

Kallio, Petri. 2006. On the earliest Slavic loanwords in Finnic. In Nuorluoto, Juhani (ed.), The Slavicization of the Russian North: Mechanisms and chronology (Slavica Helsingiensia 27), 154-166. Helsinki: Department of Slavonic and Baltic Languages and Literatures.

Kallio, Petri. 2014. The diversification of Proto-Finnic. In Ahola, Joonas \& Frog \& Tolley, Clive (eds.), Fibula, fabula, fact: The Viking Age in Finland (Studia Fennica Historica 18), 155-168. Helsinki: Finnish Literature Society. https://doi.org/10.21435/sfh.18

KARLOVA = Карлова, О. Л. 2014. Карельская антропонимия нехристианского происхождения (на материале писцовой книги Водской пятины 1500 года). In Zajceva, H. G. \& Mullonen, I. I. (eds.), V Всероссийская конферениия финно-угроведов "Финно-угорские языки и культуры в социокультурном ландшабте России», 33-36.

http://resources.krc.karelia.ru/illh/doc/knigi_stati/mater_fin_ugr_konf.pdf (Accessed: 10 November 2019.)

Kepsu, Saulo. 1987. Talonnimien tutkimisesta. In Kiviniemi, Eero \& Pitkänen, Ritva Liisa (eds.), Kieli 2, 35-73. Helsinki: Helsingin yliopiston suomen kielen laitos.

Kepsu, Saulo. 1995. Pietari ennen Pietaria: Nevansuun vaiheita ennen Pietarin kaupungin perustamista. Helsinki: Suomalaisen Kirjallisuuden Seura.

KePSU, SAULO. 2005. Uuteen maahan: Helsingin ja Vantaan vanha asutus ja nimistö. Helsinki: Suomalaisen Kirjallisuuden Seura.

KePSU, SAulo. 2010. Inkerin pogostat. Vanha nimistö ja asutus. (Unpublished manuscript.)

KEPSU, SAUlO. 2015a. Esikristilliset henkilönnimet kylännimissä. In Jüvä Sullõv (ed.), Õdagumeresuumlaisi nimeq. Läänemeresoomlaste nimed, 127-138. Võro Instituut.

KePSU, SAUlo. 2015b. Prototoponymica: Nimenanto Pohjois-Savossa eräkaudella. Virittäjä 119. 267-278.

KePsu, SAUlo. 2018. Kannaksen kylät (Kotimaisten kielten keskuksen verkkojulkaisuja 54). Helsinki.

https://www.kotus.fi/julkaisut/nimijulkaisut/kannaksen_kylat (Accessed: 1 November 2018.)

Kiviniemi, Eero. 1982. Rakkaan lapsen monet nimet: Suomalaisten etunimet ja nimenvalinta. Espoo: Weilin + Göös.

Kiviniemi, Eero. 199o. Perustietoa paikannimistä. Helsinki: Suomalaisen Kirjallisuuden Seura.

KNR = Päll, Peeter \& KallasmaA, MarJa (eds.). 2016. Eesti kohanimeraamat . Tallinn: Eesti Keele Sihtasutus. https://www.eki.ee/dict/knr/ (Accessed: 1 November 2018.)

Knyazeva, S. \& Eydlina, S. 2018. Cartographic estimation of tree parameter dynamics in Russian Northwest regions. Forest Science Issues 1(1). 1-33. 
Kon'коva = Конькова, О. И. 2008. Археологические находки на западе ленинградской области и проблема происхождения ижоры. In Sorokin, P. Е. (еd.), Археологическое наследие Санкт-Петербурга. Выпуск 2. Древности Ижорской земли. Archaeologic heritage of Saint-Petersburg. Volume 2. The ancients of the Izhora land, 9-32. Санкт-Петербург: Moscow Architecture Preservation Society (MAPS).

Kor PElA, JUKKA. 2002. Finland's eastern border after the treaty of Nöteborg: An ecclesiastical, political or cultural border? Journal of Baltic Studies 33(4). 384-394.

Korpela, JukKA. 2004. Viipurin lä̈nin historia: 2. Viipurin linnaläänin synty. Lappeenranta: Karjalan Kirjapaino.

Kritska, Aivar \& Tvauri, Andres. 2007. Viron esihistoria. Helsinki: Suomalaisen Kirjallisuuden Seura.

Kuzmin, Denis. 2014a. Vienan Karjalan asutushistoria nimistön valossa. Helsinki: Helsingin yliopisto. (Doctoral dissertation.)

Kuzmin, Denis. 2014b. The inhabitation of Karelia in the First Millennium AD in the light of linguistics. In Ahola, Joonas \& Frog \& Tolley, Clive (eds.), Fibula, fabula, fact: The Viking Age in Finland, 269-295. Helsinki: Finnish Literature Society. https://doi.org/10.21435/sfh.18

LAng, VAlter. 2018. Läänemeresoome tulemised. Finnic becomings. Tartu: Tartu Ülikooli Kirjastus.

LCD = Liber Census Daniae. (Document collection that was compiled during the first half of the 13th century. It covered the northern parts of Estonia.)

https://www.sa.dk/ao-soegesider/billedviser?epid=17004022\#123495,18115081 (Accessed: 24 December 2019.)

LeHTINEn, TAPANI. 2007. Kielen vuosituhannet: Suomen kielen kehitys kantauralista varhaissuomeen (Tietolipas 215). Helsinki: Suomalaisen Kirjallisuuden Seura.

LEIBRING, KATHARINA. 2016. Given names in European naming systems. In Hough, Carole (ed.), The Oxford handbook of names and naming, 199-213. Oxford: Oxford University Press. https://doi.org/10.1093/oxfordhb/9780199656431.013.51

Leskinen, HeIKki. 1991. Inkerin kielimuodot. In Sihvo, Hannes \& Nevalainen, Pekka (eds.), Inkeri: Historia, kansa, kulttuuri, 222-233. Helsinki: Suomalaisen Kirjallisuuden Seura.

MaкAROV = Макаров, Н. А. 1997. Колонизация северных окраин древней Руси в XI-ХІІІ вв: По материлам археологических памятников на волоках Белозерья и Поонежья. Москва: Скрипторий.

Matveev = Матвеев, А. К. 2015. Субстратная топонимия Русского Севера: 4. Топонимия мерянского типа. Екатеринбург: Издательство Уральского университета.

MIN = Андрияшев, А. М. 1914. Материаль по исторической географии Новгородской земли: Шелонская пятина по писцовым книгам 1498-1576 г.2. Москва: Имп. Общество Истории и Древностей Российских при Московском Университете.

Muinaisjäännösrekisteri [Ancient Relics Register of Finland]. https://www.kyppi.fi/palveluikkuna/mjreki/read/asp/r_default.aspx (Accessed: 1 November 2018.) 
Mullonen = Муллонен, Ирма. 2008. Топонимия Заонежья: Словарь с историко-культурными комментариями. Петрозаводск: Российская Академия наук. Карельский научный центр. Институт языка, литературы и истории.

Nevolin = Неволин, К. А. 1853. О пятинах и погостах новгородских в XVI веке, с приложением карты (Из Записок Императорского русского географического общества, Кн. VIII). Санкт-Петербург: Тип. Имп. Акад. наук.

NissıLÄ, VıLJo. 1965. Tutkimus itämerensuomalaisesta henkilönnimistöstä. Virittäjä 69. 78-89.

NPK I = Переписная оброчная книга Деревской пятины, около 1495 года (Изданные Археографической комиссией [под редакцией П. Савваитова]). Санкт-Петербург: Типография Безобразова. 1859.

NPK II = Переписная оброчная книга Деревской пятины, около 1495 года (Изданные Археографической комиссией [под редакцией П. Савваитова]). Санкт-Петербург: Типография Безобразова. 1862.

NPK III = Новгородские писцовые книги: Переписная окладная книга Водской пятины 1500(7оо8) года, Часть 1. Санкт-Петербург: Археографицеская Коммиссия. 1868.

NPK IV = Переписная оброчныя книга Шелонкой пятины. I. 1498 г., II. 1539 г., III. 1552-1553 22. (Изданные Археографическою комиссиею [ред. Павел Савваитов]). Санкт-Петербург: Типография Министерства внутренних дел. 1886.

NPK VI = Книги Бежецкой пятины: I. 1501 г., II. 1545 2., III. 1551 2., IV. 1564 г. Приготовлен к печати С.К. Богоявленским. Санкт-Петербург: Типография Безобразова. 1910.

Peruskartasto $=$ Fogelberg, Paul \& Tahvonen, Eino. 1980. Peruskartasto. Helsinki: WSOY.

Peterson, Lena. 1994. On the relationship between Proto-Scandinavian and Continental Germanic personal names. In Düwel, Klaus (ed.), Runische Schriftkultur in kontinental-skandinavischer und -angelsächsischer Wechselbeziehung: Internationales Symposium in der Werner-Reimers-Stiftung vom 24.-27. Juni 1992 in Bad Homburg (Ergänzungsbände zum Reall 10), 128-175. Berlin \& New York: Walter de Gruyter.

PIRINEN, KAUKO. 1982. Savon historia II:1. Rajamaakunta asutusliikkeen aikakautena 1534-1617. Kuopio: Kustannuskiila.

РКОР = Писиовые книги Обонежской пятинь: 1496 и 1563 г2. Под общ. ред. М. Н. Покровского. Ленинград: Академия наук Союза Советских Социалистических Республик. Археографическая комиссия. 1930.

POKV I = Переписная окладная книга по Новугороду Вотьской пятинь: $70 о 8$ года. Москва: Временник Московского общества истории и древностей. 1851.

POKV II = Переписная окладная книга по Новугороду Вотьской пятины: 7008 года. Москва: Временник Московского общества истории и древностей. 1852. 
Rahkonen, Pauli. 2011. Finno-Ugrian hydronyms of the river Volkhov and Luga catchment areas. Journal de la Société Finno-Ougrienne 93. 205-266.

Rahkonen, Pauli. 2013. South-Eastern contact area of Finnic languages in the light of onomastics. Helsinki: University of Helsinki. (Doctoral dissertation.)

Raninen, Sami \& Wessman, Anna. 2015. Rautakausi. In Haggrén, Georg \& Halinen, Petri \& Lavento, Mika \& Raninen, Sami \& Wessman, Anna (eds.), Muinaisuutemme jäljet: Suomen esi- ja varhaishistoria kivikaudelta keskiajalle, 215-364. Helsinki: Gaudeamus.

RAUnAMAA, JАAкKо. 2017. Finnish medieval village names based on anthroponyms in the Castle Province of Raseborg. In Ainiala, Terhi \& Saarikivi, Janne (eds.), Personal name systems in Finnic and beyond (Uralica Helsingiensia 12), 33-82. Helsinki: Finno-Ugrian Society.

RaunamaA, JаAкко. 2019. Pre-Christian Finnic anthroponyms in Finnish village names. In Bölcskei, Andrea \& Felecan, Oliviu \& Štěpán, Pavel (eds.), Onomastica Uralica 12. 121-135.

Rintala, Päıvi. 2008. Ihalasta Ihaviljankorpeen: Iha-vartalo Suomen henkilönja paikannimissä (Suomi 194). Helsinki: Suomalaisen Kirjallisuuden Seura.

RJABININ = Рябинин, Е. А. 1997. Финно-угорские племена в составе Древней Руси: К истории славяно-финских этнокультурных связей. Историкоархеологические очерки. Санкт-Петербург: Изд-во С.-Петербург. унта.

Ronimus, J. V. 1906. Novgorodin vatjalaisen viidenneksen verokirja v. 1500 ja Karjalan silloinen asutus. Helsinki: Suomen Historiallinen Seura.

Roos, EdUARD. 1976. Inimene ja loodus Eesti muistses antroponüümikas. In Mäger, Mart (ed.), Keel, mida me uurime, 106-119. Tallinn: Valgus.

SA = Suomen asutus 1560-luvulla: Kyläluettelot. Bebyggelsen i Finland på 1560-talet: Byförteckningarna. Pohjoismaisen autiotilatutkimuksen Suomen jaosto. Helsinki: Helsingin yliopisto, historian laitos. 1973.

SAARIKIVI, JANne. 2006. Substrata Uralica: Studies on Finno-Ugrian substrate in Northern Russian dialects. Helsinki: Helsingin yliopisto. (Doctoral dissertation.)

SAARIKIVI, JANNE. 2017. The spread of Finnic pre-Christian anthroponyms in toponyms. In Ainiala, Terhi \& Saarikivi, Janne (eds.), Personal name systems in Finnic and beyond (Uralica Helsingiensia 12), 13-31. Helsinki: Finno-Ugrian Society.

SAARIKIVI, JANNE \& GRÜNThAL, RiHo. 2005. Itämerensuomalaisten kielten uralilainen tausta. In Grünthal, Riho \& Lappalainen, Hanna \& Suutari, Toni \& Vaattovaara, Johanna (eds.), Muuttuva muoto: Kirjoituksia Tapani Lehtisen 6o-vuotispäivän kunniaksi, 111-146. Helsinki: Helsingin yliopiston suomen kielen laitos.

SAK = Suomen asutus 156o-luvulla: Kartasto. Pohjoismaisen autiotilatutkimuksen Suomen jaosto. Helsinki: Suomen Historiallinen Seura. 1973.

Saksa, Aleksandr \& Uino, Pirjo \& Hiekranen, Markus. 2003. Ristiretkiaika 1100-1300 jKr. In Saarnisto, Matti (ed.), Viipurin läänin historia I: Karjalan synty, 383-474. Lappeenranta: Karjalan kirjapaino. 
SAlWAY, BENET. 1994. What's in a name? A survey of Roman onomastic practice from c. 700 B.C. to A.D. 700. Journal of Roman Studies 84. 124-145.

SAYL = Suomen asutuksen yleisluettelo. http://www.narc.fi/Arkistolaitos/SAY/ (Accessed: 1 November 2018.)

Scandinavian Runic-text Database. https://www.nordiska.uu.se/forskn/samnord.htm (Accessed: 31 January 2019.)

Schalin, Johan. 2018. Preliterary Scandinavian sound change viewed from the east: Umlaut remodelled and language contact revisited. Helsingfors: Helsingfors universitet. (Doctoral dissertation.)

SDHK $=$ Svenskt Diplomatariums huvudkartotek över medeltidsbreven. https://sok.riksarkivet.se/SDHK (Accessed: 1 November 2018.)

SEdov = Седов, В. В. 1982. Восточные славяне в VI-XIII вв. Москва: Российская академия наука.

Sedov = Седов, В. В. 1995. Славяне в раннем средневековье. Москва: Научнопроизводственное благотворительное общество «Фонд археологии».

Seppälä, SuviAnnA. 2009. Viljana, nahkoina, kapakalana: Talonpoikien maksamat kruununverot suomessa vuosina 1539-1609. Helsinki: Suomalaisen Kirjallisuuden Seura.

Sjögren, Andreas Johan. 1861. Gesammelte Schriften: Band 1. Historisch-ethnographische Abhandlungen über den finnisch-russischen Norden. St. Petersburg: Commissionäre der Kaiserlichen Akademie der Wissenschaften.

ŠNĒ, ANDRIS. 2008. The medieval peasantry: On the social and religious position of the rural natives in southern Livonia (13th-15th centuries). Ajalooline Ajakiri 1/2 (123/124). 89-100.

SoBolev = Соболев, А. И. 2017. Антропонимы прибалтийско-финского происхождения в писцовых книгах Юго-Восточного Обонежья XV-XVI вв. Вопросы ономастики 14 (1). 7-34.

https://doi.org/10.15826/vopr_onom.2017.14.1.0o1

Soroкin = Сорокин, П. Е. 2008. Археологическое изучение средневековых памятников в Приневье: Новые данные по археологии ижоры. In Sorokin, P. Е. (еd.), Археологическое наследие Санкт-Петербурга. Выпуск 2. Древности Ижорской земли. Archaeologic heritage of Saint-Petersburg. Volume 2. The ancients of the Izhora land, 88-127. Санкт-Петербург: Moscow Architecture Preservation Society (MAPS).

SPNK = PAIKKALA, SIRKKA (ed.). 2007. Suomalainen paikannimikirja. Helsinki: Karttakeskus \& Kotimaisten kielten tutkimuskeskus.

SSA = ITKONEN, ERKKI \& KULONEN, Ulla-MAIJA (eds.). 1992-200o. Suomen sanojen alkuperä 1-3: Etymologinen sanakirja. Helsinki: Suomalaisen Kirjallisuuden Seura: Kotimaisten kielten tutkimuskeskus.

STASJUK = Стасюк, И. В. 2013. Новые находки оружия римского времени и эпохи Меровингов на северо-западе России. Stratum plus 4. 133-146.

Stoebke, D. E. 1964. Die alten ostseefinnischen Personennamen im Rahmen eines urfinnischen Namensystems. Hamburg: Leibniz.

SuPERANSKAJA = Суперанская, А. В. 2009. Словарь народных форм русских имен. Москва: Либроком. 


\section{Distribution of village names}

Toikka-Karvonen, Annikki. 1990. Inkerin tie itsenäisyystaisteluun. In Laaksonen, Pekka \& Mettomäki, Sirkka-Liisa (eds.), Inkerin teillä (Kalevalaseuran vuosikirja 69-70), 167-183. Helsinki: Suomalaisen Kirjallisuuden Seura.

Uino, PirJo. 1991. Inkerinmaan esihistoria. In Sihvo, Hannes \& Nevalainen, Pekka (eds.), Inkeri: Historia, kansa, kulttuuri, 11-34, 361-364. Helsinki: Suomalaisen Kirjallisuuden Seura.

Uino PirJo. 2003. Keskirautakausi n. 300-80o jKr. \& Viikinkiaika n. 80o-110o jKr. In Saarnisto, Matti (ed.), Viipurin läänin historia I: Karjalan synty, 291382. Lappeenranta: Karjalan kirjapaino.

USNK = Huitu, Marketta \& Mikkonen, Pirjo \& Paikkala, Sirkka \& VilkuNA, KustaA. 1988. Uusi suomalainen nimikirja. Helsinki: Otava.

VAнtola, Jouko. 1980. Tornionjoki- ja Kemijokilaakson asutuksen synty: Nimistötieteellinen ja historiallinen tutkimus. Rovaniemi: Pohjois-Suomen historiallinen yhdistys.

VAнтоla, Jouko. 2003. Suomen historia: Jääkaudesta Euroopan unioniin. Helsinki: Otava.

Valtonen, TaArna. 2017. Anthroponyms in the Saami languages. In Ainiala, Terhi \& Saarikivi, Janne (eds.), Personal name systems in Finnic and beyond (Uralica Helsingiensia 12), 287-324. Helsinki: Finno-Ugrian Society.

Viтоv = Витов, М. В. 1962. Историко-географические очерки Заонежья XVIXVII веков: Из истории сельских поселений. Москва: Издательство Московского университета.

VoIONMAA, VÄInÖ. 1969. Suomen karjalaisen heimon historia. Porvoo: WSOY.

Wessman, Anna. 2016. Women along the river banks: New Iron Age finds from Espoo. In Harjula, Janne \& Helamaa, Maija \& Haarala, Janne \& Immonen, Visa (eds.), Mankby: A deserted medieval village on the coast of Southern Finland. Turku: The Society for Medieval Archaeology in Finland.

Worth, Dean S. \& Flier, Michael S. 2012. Language. In Rzhevsky, Nicholas (ed.), The Cambridge companion to modern Russian culture (2nd edition), 1743. Cambridge: Cambridge University Press.

Zetterberg, Seppo. 2007. Viron historia. Helsinki: Suomalaisen Kirjallisuuden Seura. 
Appendix: List of village names ${ }^{1}$

\begin{tabular}{|c|c|c|}
\hline Name & Location & Source \\
\hline Auvainen & Turku & SA: 31 \\
\hline Auvainen & Kaarina & SA: 43 \\
\hline Auvainen & Loimaa & SA: 84 \\
\hline Auvainen & Eura & SA: 91 \\
\hline Auvaismäki & Turku & SA: 26 \\
\hline Auvere & Narva-Jõesuu & KNR s.v. Auvere \\
\hline Auvi & Eurajoki & SA: 92 \\
\hline Auvila & Jämsä & SA: 152 \\
\hline Auvila & Juva & SA: 228 \\
\hline Auvila & Sulkava & SA: 232 \\
\hline Auvola & Masku & SA: 17 \\
\hline Auvola & Paimio & SA: 60 \\
\hline Avvala & Всеволжский & POKV1: 214 \\
\hline Gavguevo & Санкт-Петербург & POKV1: 358 \\
\hline Gjulelě & Санкт-Петербург & POKV1: 348 \\
\hline Gjuvila & Кировский & POKV1: 266 \\
\hline Haimre & Märjamaa & KNR s.v. Haimre \\
\hline Heimala & Выборгский & SA: 205 \\
\hline Heimala & Выборгский & SA: 216 \\
\hline Heimola & Lohja & SA: 177 \\
\hline Heimos & Raasepori & SA: 161 \\
\hline Hjulböle & Pori & SA: 94 \\
\hline Hyökkälä & Tuusula & SA: 182 \\
\hline Hyövelä & Taivassalo & SA: 2 \\
\hline Hyvälempelä & Parainen & SA: 51 \\
\hline Hyväneula & Hollola & SA: 143 \\
\hline Hyvärilä & Lemi & SA: 204 \\
\hline Hyvärilä & Sulkava & SA: 232 \\
\hline Hyvättilä & Lappeenranta & SA: 203 \\
\hline Hyvättylä & Lieto & SA: 40 \\
\hline Hyvelä & Lohja & SA: 165 \\
\hline
\end{tabular}

1. See Section 4.1 for details and explanations. 
Distribution of village names

\begin{tabular}{|c|c|c|}
\hline Name & Location & Source \\
\hline Hyvikkälä & Janakkala & SA: 121 \\
\hline Hyvinkää & Hyvinkää & SA: 121 \\
\hline Ičjapovo & Кингисеппский & NPK III: 509 \\
\hline Igačino & Олонецкий & PKOP: 68 \\
\hline Igaevo & Струго-Красненский & MIN: 70 \\
\hline Igakšala & Сортавала & POKV2: 150 \\
\hline Igala & Лахденпохский & POKV2: 124 \\
\hline Igalkovo & Выборгский & POKV1: 229 \\
\hline Igandova & Тосненский & POKV1: 423 \\
\hline Igandovo & Кировский & POKV1: 439 \\
\hline Igaver & Are & KNR s.v. Eavere \\
\hline Igavere & Raasiku & KNR s.v. Igavere ${ }^{1}$ \\
\hline Igavere & Tartu & KNR s.v. Igavere ${ }^{2}$ \\
\hline Igoe & Пудожский & PKOP: 173 \\
\hline Igojškoe & Прионежский & PKOP: 119 \\
\hline Igolino & Kitee & POKV2: 144 \\
\hline Igolkino & Всеволжский & PKOP: 207 \\
\hline Igolkino & Всеволжский & POKV1: 170 \\
\hline Igomel & Плюсский & MIN: 92 \\
\hline Ihaksela & Lappeenranta & SA: 205 \\
\hline Ihala & Puumala & SA: 220 \\
\hline Ihala & Raisio & SA: 32 \\
\hline Ihalainen & Lappeenranta & SA: 204 \\
\hline Ihalainen & Mynämäki & SA: 22 \\
\hline Ihalempiälä & Выборгский & SA: 209 \\
\hline Ihalempinen & Hattula & SA: 120 \\
\hline Ihamaru & Kõlleste & KNR s.v. Ihamaru \\
\hline Ihamuotila & Turku & SA: 29 \\
\hline Ihanttula & Taivassalo & SA: 1 \\
\hline Ihaste & Tartu & KNR s.v. Ihaste \\
\hline Ihode & Pyhäranta & SA: 12 \\
\hline Ihola & Выборгский & SA: 199 \\
\hline Ikaala & Urjala & SA: 128 \\
\hline Ikaalinen & Ikaalinen & SA: 103 \\
\hline Ikaaloinen & Janakkala & SA: 124 \\
\hline
\end{tabular}




\begin{tabular}{|c|c|c|}
\hline Name & Location & Source \\
\hline Ikaevo & Санкт-Петербург & POKV1: 347 \\
\hline Ikätorola & Ruokolahti & SA: 210 \\
\hline Ikelä & Salo & SA: 61 \\
\hline Ikiälä & Выборгский & SA: 215 \\
\hline Ikoila & Mikkeli & SA: 220 \\
\hline Ikoinniemi & Savonlinna & SA: 231 \\
\hline Ikola & Выборгский & SA: 217 \\
\hline Ikola & Juva & SA: 229 \\
\hline Ilmari & Ylöjärvi & SA: 105 \\
\hline Ilmarinen & Lieto & SA: 40 \\
\hline Ilmarinen & Vehmaa & SA: 8 \\
\hline Ilmarinen & Loimaa & SA: 85 \\
\hline Ilmatoivola & Выборгский & SA: 213 \\
\hline Il'mia & Rautjärvi & POKV2: 24 \\
\hline Ilmola & Keminmaa & SA: 256 \\
\hline Ilmuevo & Приозерский & POKV1: 179 \\
\hline Kaugatoma & Saaremaa & KNR s.v. Kaugatoma \\
\hline Kaugu & Rõuge & KNR s.v. Kaugu \\
\hline Kaukela & Lohja & SA: 166 \\
\hline Kaukelmaa & Salo & SA: 64 \\
\hline Kaukila & Выборгский & SA: 215 \\
\hline Kaukka & Pyhäranta & SA: 10 \\
\hline Kaukkala & Pälkäne & SA: 147 \\
\hline Kaukkiala & Jämsä & SA: 152 \\
\hline Kauklainen & Rauma & SA: 13 \\
\hline Kaukoila & Vihti & SA: 174 \\
\hline Kaukoinen & Naantali & SA: 17 \\
\hline Kaukoinen & Masku & SA: 19 \\
\hline Kaukola & Kangasala & SA: 111 \\
\hline Kaukola & Laitila & SA: 12 \\
\hline Kaukola & Tammela & SA: 131 \\
\hline Kaukola & Rauma & SA: 14 \\
\hline Kaukola & Hämeenlinna & SA: 148 \\
\hline Kaukola & Padasjoki & SA: 149 \\
\hline Kaukola & Lohja & SA: 160 \\
\hline
\end{tabular}




\begin{tabular}{|c|c|c|}
\hline Name & Location & Source \\
\hline Kaukola & Kotka & SA: 191 \\
\hline Kaukola & Seinäjoki & SA: 245 \\
\hline Kaukola & Vehmaa & SA: 3 \\
\hline Kaukola & Sauvo & SA: 48 \\
\hline Kaukola & Salo & SA: 62 \\
\hline Kaukola & Salo & SA: 65 \\
\hline Kaukola & Sastamala & SA: 98 \\
\hline Kaukolempi & Lappeenranta & SA: 203 \\
\hline Kaukolempiälä & Выборгский & SA: 210 \\
\hline Kaukonpieli & Eurajoki & SA: 92 \\
\hline Kauksi & Alutaguse & KNR s.v. Kauksi ${ }^{1}$ \\
\hline Kauksi & Põlva & KNR s.v. Kauksi ${ }^{2}$ \\
\hline Kaukurla & Mynämäki & SA: 21 \\
\hline Kauvainen & Mynämäki & SA: 24 \\
\hline Kauvonniemi & Savonlinna & SA: 225 \\
\hline Kavastu & Haljala & KNR s.v. Kavastu ${ }^{1}$ \\
\hline Kavastu & Luunja & KNR s.v. Kavastu ${ }^{2}$ \\
\hline Kavgala & Приозерский & POKV2: 21 \\
\hline Kavgalě & Всеволжский & POKV1: 201 \\
\hline Kavgovalda & Лахденпохский & POKV2: 123 \\
\hline Kavgovone & Питкярантский & PKOP: 71 \\
\hline Kavguevskoe & Гатчинский & POKV1: 381 \\
\hline Kavgulě & Тосненский & POKV1: 422 \\
\hline Kir'elě & Кировский & POKV1: 86 \\
\hline Kirila & Paide & KNR s.v. Kirila \\
\hline Kirimäe & Lääne-Nigula & KNR s.v. Kirimäe \\
\hline Kirisaare & Paide & KNR s.v. Kirisaare \\
\hline Kiritu & Saaremaa & KNR s.v. Kiritu \\
\hline Kirivalla & Kose & KNR s.v. Kirivalla \\
\hline Kirivere & Põhja-Sakala & KNR s.v. Kirivere ${ }^{1}$ \\
\hline Kirivere & Jõgeva & KNR s.v. Kirivere ${ }^{2}$ \\
\hline Kirjais & Parainen & SA: 50 \\
\hline Kirjakkala & Salo & SA: 63 \\
\hline Kir'jakšino & Сортавала & POKV2: 157 \\
\hline Kirjala & Hartola & SA: 151 \\
\hline
\end{tabular}




\begin{tabular}{|c|c|c|}
\hline Name & Location & Source \\
\hline Kirjala & Naantali & SA: 34 \\
\hline Kirjala & Parainen & SA: 52 \\
\hline Kirjamo & Lempäälä & SA: 113 \\
\hline Kirjavala & Выборгский & SA: 218 \\
\hline Kirjola & Salo & SA: 62 \\
\hline Kirumpää & Võru & KNR s.v. Kirumpää \\
\hline Kjuljatikov & Санкт-Петербург & POKV1: 306 \\
\hline Kjullině & Санкт-Петербург & POKV1: 411 \\
\hline Kjulljujevo & Гатчинский & NPK III: 695 \\
\hline Koukkala & Parainen & SA: 51 \\
\hline Külitse & Kambja & KNR s.v. Külitse \\
\hline Kyllelä & Paimio & SA: 58 \\
\hline Kylliälä & Выборгский & SA: 200 \\
\hline Kylliälä & Savitaipale & SA: 207 \\
\hline Kyllölä & Puumala & SA: 220 \\
\hline Lomestaekiloe & Saue & KNR s.v. Pällu ${ }^{1}$ \\
\hline Lämmis & Sauvo & SA: 44 \\
\hline Lehmja & $\mathrm{Rae}$ & KNR s.v. Lehmja ${ }^{1}$ \\
\hline Lehmja & Saue & KNR s.v. Lehmja ${ }^{2}$ \\
\hline Lembagalě & Всеволжский & POKV1: 145 \\
\hline Lembevere & Elva & KNR s.v. Lembevere \\
\hline Lembievo & Санкт-Петербург & POKV1: 353 \\
\hline Lembina & Кировский & POKV1: 56 \\
\hline Lembitov & Кондопожский & PKOP: 127 \\
\hline Lembitovo & Санкт-Петербург & POKV1: 204 \\
\hline Lembitovo & Санкт-Петербург & POKV1: 416 \\
\hline Lemboče & Прионежский & PKOP: 115 \\
\hline Lemboj & Медвежьегорский & PKOP: 2 \\
\hline Lemmätsi & Rõuge & KNR s.v. Lemmätsi \\
\hline Lemmettylä & Pälkäne & SA: 146 \\
\hline Lemmettylä & Mynämäki & SA: 21 \\
\hline Lemmetyinen & Taivassalo & SA: 3 \\
\hline Lemmikküla & Lääne-Nigula & KNR s.v. Lemmikküla \\
\hline Lemmittylä & Uusikaupunki & SA: 11 \\
\hline Lemmküla & Tapa & KNR s.v. Lemmküla \\
\hline
\end{tabular}




\begin{tabular}{|c|c|c|}
\hline Name & Location & Source \\
\hline Lempälä & Turku & SA: 43 \\
\hline Lempans & Siuntio & SA: 171 \\
\hline Lempiälä & Выборгский & SA: 204 \\
\hline Lempiälä & Ruokolahti & SA: 210 \\
\hline Lempiälä & Выборгский & SA: 210 \\
\hline Lempiäniemi & Ylöjärvi & SA: 106 \\
\hline Lempilä & Salo & SA: 57 \\
\hline Lempilä & Salo & SA: 64 \\
\hline Lempiö & Vehmaa & SA: 6 \\
\hline Lempiskallio & Mynämäki & SA: 21 \\
\hline Lempoinen & Lempäälä & SA: 112 \\
\hline Lempoinen & Masku & SA: 19 \\
\hline Lempoinen & Taivassalo & SA: 22 \\
\hline Lempoinen & Kokemäki & SA: 91 \\
\hline Lempola & Seinäjoki & SA: 245 \\
\hline Lemuvere & Jõgeva & KNR s.v. Lemuvere \\
\hline Lenekale & Приозерский & P2: 119 \\
\hline Meelaku & Rõuge & KNR s.v. Meelaku \\
\hline Meeliku & Võru & KNR s.v. Meeliku \\
\hline Meelva & Lääneranna & KNR s.v. Meelva ${ }^{1}$ \\
\hline Meelva & Lääne & KNR s.v. Meelva ${ }^{2}$ \\
\hline Melanculoe & Lääne-Harju & KNR s.v. Padise \\
\hline Melitovo & Приозерский & POKV2: 115 \\
\hline Mellaes & Haljala & KNR s.v. Kavastu \\
\hline Melliste & Kastre & KNR s.v. Melliste \\
\hline Mielaanniemi & Sastamala & SA: 99 \\
\hline Mielis & Parainen & SA: 50 \\
\hline Mielisholm & Parainen & SA: 52 \\
\hline Mielismäki & Mynämäki & SA: 22 \\
\hline Miettula & Paimio & SA: 59 \\
\hline Miettylä & Laihia & SA: 246 \\
\hline Neuvoinen & Mynämäki & SA: 21 \\
\hline Neuvola & Выборгский & SA: 217 \\
\hline Neuvola & Pieksämäki & SA: 225 \\
\hline Neuvottoma & Hamina & SA: 191 \\
\hline
\end{tabular}




\begin{tabular}{|c|c|c|}
\hline Name & Location & Source \\
\hline Nevas & Sipoo & SA: 181 \\
\hline Nõuni & Palupera & KNR s.v. Nõuni \\
\hline Ontika & Toila & KNR s.v. Ontika \\
\hline Päädeva & Märjamaa & KNR s.v. Päädeva \\
\hline Pääväkese & Võru & KNR s.v. Pääväkese \\
\hline Päivälä & Heinävesi & SA: 234 \\
\hline Päivilä & Savonlinna & SA: 230 \\
\hline Pjajala & Всеволжский & POKV1: 162 \\
\hline Toitino & Тосненский & POKV1: 425 \\
\hline Toivaala & Hämeenlinna & SA: 146 \\
\hline Toivakala & Приозерский & POKV1: 186 \\
\hline Toivala & Siilinjärvi & SA: 239 \\
\hline Toivalově & Санкт-Петербург & POKV1: 294 \\
\hline Toivarila & Lappeenranta & SA: 205 \\
\hline Toivekala & Санкт-Петербург & POKV1: 364 \\
\hline Toiviala & Ruokolahti & SA: 211 \\
\hline Toivila & Jämsä & SA: 152 \\
\hline Toivila & Salo & SA: 57 \\
\hline Toivola & Hollola & SA: 142 \\
\hline Toivola & Sysmä & SA: 150 \\
\hline Toivola & Выборгский & SA: 218 \\
\hline Toivola & Mäntyharju & SA: 223 \\
\hline Toivottula & Akaa & SA: 133 \\
\hline Tojvala & Санкт-Петербург & POKV1: 204 \\
\hline Tojvetove & Лодейнопольский & PKOP: 245 \\
\hline Tojvine & Медвежьегорский & PKOP: 151 \\
\hline Tojvoevo & Приозерский & POKV2: 105 \\
\hline Tojvokalě & Гатчинский & POKV1: 343 \\
\hline Tootula & Lieto & SA: 39 \\
\hline Unoes & Haljala & KNR s.v. Kavastu \\
\hline Unaja & Rauma & SA: 13 \\
\hline Unaja & Sysmä & SA: 151 \\
\hline Unajala & Vesilahti & SA: 114 \\
\hline Unakvere & Põhja-Sakala & KNR s.v. Unakvere \\
\hline Undama & Hiiumaa & KNR s.v. Undama \\
\hline
\end{tabular}




\begin{tabular}{|c|c|c|}
\hline Name & Location & Source \\
\hline Undijala & Сортавала & POKV2: 147 \\
\hline Undla & Kadrina & KNR s.v. Undla \\
\hline Undva & Saaremaa & KNR s.v. Undva \\
\hline Uneste & Haapsalu & KNR s.v. Uneste \\
\hline Uniküla & Kastre & KNR s.v. Uniküla ${ }^{2}$ \\
\hline Uniküla & Valga & KNR s.v. Uniküla ${ }^{3}$ \\
\hline Unipiha & Nõo & KNR s.v. Unipiha \\
\hline Univere & Karksi & KNR s.v. Univere \\
\hline Unonen & Hämeenlinna & SA: 128 \\
\hline Untamala & Laitila & SA: 12 \\
\hline Untila & Hämeenkyrö & SA: 103 \\
\hline Untila & Hollola & SA: 142 \\
\hline Untola & Turku & SA: 26 \\
\hline Unukse & Viru-Nigula & KNR s.v. Unukse \\
\hline Valaste & Toila & KNR s.v. Valaste \\
\hline Valasti & Paide & KNR s.v. Valasti \\
\hline Valdola & Лахденпохский & POKV2: 122 \\
\hline Vallainen & Mynämäki & SA: 21 \\
\hline Valto & Valkeakoski & SA: 129 \\
\hline Valtola & Lappeenranta & SA: 203 \\
\hline Valtola & Mynämäki & SA: 22 \\
\hline Valtola & Puumala & SA: 234 \\
\hline Vea & Jõgeva & KNR s.v. Vea \\
\hline Vehendi & Elva & KNR s.v. Vehendi \\
\hline Vichterica & Кировский & POKV1: 264 \\
\hline Vigorě & Санкт-Петербург & NPK III: 829 \\
\hline Vihainen & Vesilahti & SA: 113 \\
\hline Vihattu & Hollola & SA: 142 \\
\hline Vihattula & Sastamala & SA: 100 \\
\hline Vihavu & Puhja & KNR s.v. Vihavu \\
\hline Vihola & Nokia & SA: 106 \\
\hline Vihola & Выборгский & SA: 214 \\
\hline Vihtiälä & Sastamala & SA: 102 \\
\hline Vihtiälä & Kangasala & SA: 109 \\
\hline Vihtola & Lappeenranta & SA: 205 \\
\hline
\end{tabular}




\begin{tabular}{|c|c|c|}
\hline Name & Location & Source \\
\hline Vihula & Haljala & KNR \\
\hline Vila & Haljala & KNR \\
\hline Vilikině & Кингисеппский & NPK III: 916 \\
\hline Vilikino & Гатчинский & POKV1: 347 \\
\hline Vilita & Türi & KNR s.v. Vilita \\
\hline Vilivalla & Hiiumaa & KNR s.v. Vilivalla ${ }^{1}$ \\
\hline Vilivalla & Lääne-Harju & KNR s.v. Vilivalla ${ }^{2}$ \\
\hline Viljainen & Naantali & SA: 35 \\
\hline Viljainen & Vehmaa & SA: 7 \\
\hline Viljakino & Всеволжский & POKV1: 194 \\
\hline Viljakinskoe & Ломоносовский & NPK III: 632 \\
\hline Viljakkala & Ylöjärvi & SA: 104 \\
\hline Viljakkala & Mikkeli & SA: 224 \\
\hline Viljala & Ikaalinen & SA: 103 \\
\hline Viljandi & Viljandi & KNR s.v. Viljandi \\
\hline Viljatova & Сегежский & PKOP: 157 \\
\hline Viljattula & Lokalahti & SA: 7 \\
\hline Villa & Haanja & KNR s.v. Villa \\
\hline Villakvere & Väike-Maarja & KNR s.v. Villakvere \\
\hline Villandi & Haljala & KNR s.v. Villandi \\
\hline Vilokala & Приозерский & POKV2: 64 \\
\hline Vilovaldina & Кировский & POKV1: 433 \\
\hline Viluevo & Санкт-Петербург & POKV1: 357 \\
\hline Vviluevo & Кингисеппский & NPK III: 929 \\
\hline Vygaleněvě & Санкт-Петербург & POKV1: 340 \\
\hline Vyljagi & Тосненский & NPK III: 369 \\
\hline Vytchotula & Волховский & POKV1: 274 \\
\hline Yläkirjola & Выборгский & SA: 199 \\
\hline Ytterölmos & Kemiönsaari & SA: 72 \\
\hline
\end{tabular}

